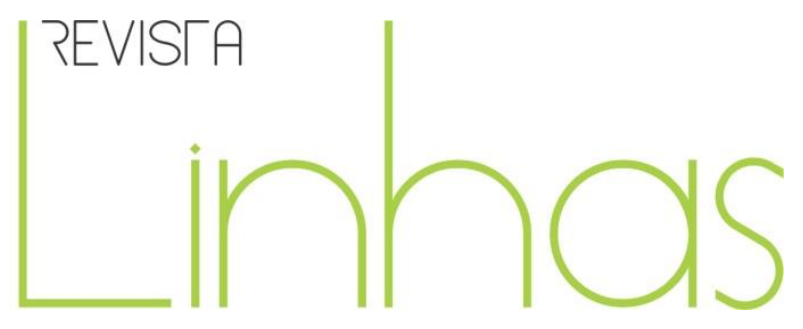

\title{
A história da atenção à criança e da infância no Brasil e o surgimento da creche e da pré-escola
}

\begin{abstract}
Resumo
A finalidade será discorrer sobre a trajetória histórica de atendimento à criança e da infância com objetivo de observar os progressos e anacronismos implicados no surgimento da creche e da pré-escola no Brasil e no seu papel social, político e pedagógico. Observar o movimento não linear de constituição das Instituições de Educação Infantil é o meio de compreendermos os seus desafios atuais, sobretudo, de ligar as questões sociais, políticas e econômicas de cada período histórico com as concepções e interesses que permeiam sua origem. As instituições de atendimento à criança passaram pela caridade, filantropia, assistencialismo, custódia, pelo caráter compensatório, até a função educativa, de tal modo que o adulto responsável pela atenção à criança teve seu perfil profissional alterado pela exigência de ser capaz de acolher as peculiaridades da faixa etária com vistas à garantia da educação e cuidado de forma integrada. Do ponto de vista histórico, houve um avanço significativo da legislação e dos documentos oficiais do MEC a partir da Constituição Federal de 1988, ocasião em que a criança de zero a seis anos é elevada à condição de cidadã, sujeito de direitos, inclusive, o direito à educação desde o seu nascimento e a Educação Infantil é apontada como fundamental ao seu desenvolvimento. A despeito das metas legais, ainda há descompasso entre o que estas propõem e a condição vivida pelas crianças e adultos nas instituições.
\end{abstract}

Palavras-chave: Brasil. Educação Infantil. Infância. Criança. Atendimento.

\section{Para citar este artigo:}

GUIMARÃES, Célia Maria. A história da atenção à criança e da infância no Brasil e o surgimento da creche e da pré-escola. Revista Linhas. Florianópolis, v. 18, n. 38, p. 80-142, set./dez. 2017. 


\title{
The history of child and childhood care in Brazil and the emergence of the nursery school and the preschool
}

\begin{abstract}
The aim of this study is to discuss the historical path of the child and childhood care observing the progress and anachronisms which are implied in the emergence of the nursery school and preschool in Brazil and its social, political and pedagogical role. Observing the nonlinear movement of constitution of the Early childhood Education Institutions is the means of understanding their current challenges, mainly, the means of connecting the social, political and economic issues of each historical period to the conceptions and interests which permeate its origin. The child care institutions have gone through the charity, philanthropy, assistentialism, custody and through the compensatory character until the educational function, so the adult who is responsible for the child attention has had his or her professional profile modified by the requirement to be able to welcome the peculiarities of the age range in order to guarantee the education and child care in an integrated way. From the historical point of view, there has been a significant progress of the legislation and MEC (Education Department) legal documents since the Federal Constitution of 1988, when the zero to sixyear-old children were promoted to the status of citizen, having their rights; moreover, the right of education since their birth and the Early childhood Education are considered fundamental points to their development. Despite legal goals, there is still the difference between what they propose and the condition lived by the children and adults in the institutions.
\end{abstract}

Keywords: Brazil. Early Childhood Education. Childhood. Child. Child Care. 


\section{Introdução}

Kuhlmann Jr. (1998, p. 22) assegura que “[...] o Sentimento de infância não seria inexistente em tempos antigos ou na Idade Média [...]". Por isso, a importância de buscarmos diferentes compreensões sobre como se exprime a infância em distintos momentos e espaços e considerar que estas concepções se entrelaçam e se interpenetram nos períodos da história, além de deixarem um legado para as compreensões atuais. KUHLMANN (1998) entende que:

É preciso considerar a infância como uma condição da criança. O conjunto das experiências vividas por elas em diferentes lugares históricos, geográficos e sociais é muito mais do que uma representação dos adultos sobre essa fase da vida. É preciso conhecer as representações de infância e considerar as crianças concretas, localizá-las como produtoras da história. (KUHLMANN, 1998, p. 30)

O conceito de infância não é um fenômeno estático e universal, pois se relaciona ao contexto em que a criança está inserida, sem que com esse entendimento seja ignorado que crianças têm necessidades e características próprias.

A forma como o mundo adulto imaginou a particularidade do universo infantil até mais ou menos o século XVI ilustra um tipo de sentimento de infância baseado na ignorância acerca do mundo da criança e sublinha o conceito de infância como resultado de uma estrutura social, política e econômica. A ausência da compreensão da especificidade do tempo de ser criança explica em boa parte o atendimento precário às crianças; o descaso com o alto índice de mortalidade infantil devido ao perigo constante de óbito pós-natal e às péssimas condições de saúde e higiene da população em geral e das crianças, em especial, em vários momentos da história. Convém ainda destacar que a infância, como uma etapa de atenção particular com a criança, destacada do mundo adulto, longe do trabalho e educada nas escolas atingiu primeiro as crianças das classes abastadas.

É na Modernidade que acontece uma intensificação de novas idéias sobre a criança e a infância por meio de estudos que desenvolvem novos saberes e entendimentos a respeito de práticas sobre como educar e conhecer as crianças. Estes conhecimentos 
produzem outros modos de entender e atender a infância no âmbito familiar e institucional que foram marcando as práticas da assistência à infância de diferentes momentos históricos e em diferentes contextos. Kramer (2006) completa:

A inserção concreta das crianças e seus papéis variam com as formas de organização da sociedade. Assim, a ideia de infância não existiu sempre da mesma maneira. Ao contrário, a noção de infância surgiu com a sociedade capitalista, urbano-industrial, na medida em que mudavam a inserção e o papel social da criança na comunidade. (KRAMER, 2006, p. 14)

Kuhlmann Junior (1998) reforça a estreita relação entre a história das instituições de educação infantil e as demandas da história da infância, da sociedade, da família, do trabalho, da urbanização, entre outros. Assim é que a história da criança no Brasil nos remete à própria história do Brasil. Há uma relação intrínseca entre o histórico da atenção à infância no Brasil e a concepção de criança e de sociedade manifesta no atendimento assistencialista, passando pelo atendimento compensatório ou preparatório e, no tempo presente, com a concepção educativa que legalmente engloba cuidados e educação. Em todas as épocas, as concepções dos propositores de políticas públicas, os interesses econômicos e políticos, as visões dos professores de menores de sete anos de idade sobre criança e infância são juízos que abonam (ou não) determinados modos de compreendê-la e, consequentemente, de proporcionar atendimento e de educá-la por meio das práticas escolhidas.

Com este texto, temos a pretensão de refletir sobre o atendimento à infância e à criança no Brasil que entre anacronismos e progressos tem decorrido em meio ao abandono, à pobreza, ao favor e à caridade. Interessa-nos fazer entender que a concepção de criança e de infância norteia o tipo de acolhimento instituído e que esta se transforma sendo continuamente condicionada e tangenciada pelas questões sociais, econômicas e políticas de cada período histórico. 


\section{A história da atenção à criança e da infância no Brasil e o surgimento da creche e da pré-escola}

Inspirada na organização de Moncorvo Filho', Kramer (2003) a revisa e propõe três fases para situar historicamente a atenção à criança no Brasil: a primeira se inicia com descobrimento em 1500, até 1874; a segunda fase, de 1874 até 1889; e a terceira fase, de 1889 até 1930. Em seguida, de 1930 até 1990 e dessa década aos dias atuais, com a indicação legal ao atendimento integral à criança articulando cuidados à sua educação na etapa da Educação Infantil. Para o tópico a seguir, utilizaremos esta estrutura com objetivo de organizá-lo pensando em aproximar o melhor possível da finalidade proposta para este texto.

\section{A atenção à criança no Brasil do descobrimento em 1500 até 1874: a caridade}

Kramer (2003, p. 48) comenta que, do descobrimento até 1874, "pouco se fazia no Brasil pela infância desditosa, tanto do ponto de vista da proteção jurídica, quanto das alternativas de atendimento existentes". Ainda no Brasil Colonial, a primeira forma de atendimento à infância brasileira decorreu da chegada dos portugueses, seguida da vinda dos Jesuítas com a incumbência de "civilizar" os índios através dos preceitos do Cristianismo. A fundação em São Vicente, em 1554, da primeira escola jesuítica no Brasil com objetivo de converter os índios ao Cristianismo se insere na história do atendimento à infância com uma matriz "[...] cristã que sustentou as diferentes práticas e políticas públicas para as populações indígenas [...]" (AMOROSO, 2011, p. 207).

Em resposta à resistência pelos índios adultos, a catequese jesuíta, sob a justificativa de que seria mais fácil envolver as crianças índias com os ensinamentos da Companhia de Jesus (ordem religiosa fundada em 1540), iniciou a prática da segregação das crianças índias em locais chamados de "casas de muchachos". Assim, estas eram retiradas das famílias e, neste local, catequizadas juntamente com crianças órfãs portuguesas da mesma faixa etária, sob a alegação que aprenderiam modos civilizados, ou seja, hábitos europeus. Deste modo, a doutrinação dos jesuítas atendia ao imperativo

\footnotetext{
${ }^{1}$ A classificação mencionada se encontra no livro Histórico da proteção à infância no Brasil, 1500-1922. Rio de Janeiro, Emp. Graphica Ed., 1926.
} 
de auxiliar a sedimentar a cultura teocrática portuguesa na colônia, além de transformar a população de índios em força de trabalho.

Os jesuítas demarcaram o início da história da educação com uma natureza essencialmente religiosa e uma imagem de criança a exemplo de uma folha de papel em branco, moldável e educável para a obediência e disciplina. Conforme afirma Farias (2005), a essa época já houve atendimento educativo, pedagógico e assistencial. Durante o período escravista, a infância no Brasil era vista de uma forma bem próxima àquelas mencionadas por Ariès (1981). Portanto, é admissível dizer que no Século XVI se encontrem os indícios do desenvolvimento da consciência de infância no Brasil:

[...] os jesuítas desenvolveram a estratégia de sua catequese alicerçada na educação dos pequenos indígenas, e trouxeram crianças órfãs de Portugal para atuarem como mediadoras nessa relação; ou então, na inovação dos colégios, com a Ratio Studiorum, o programa educacional jesuítico, que estabeleceu as classes separadas por idade e a introdução da disciplina. (KUHLMANN JUNIOR, 1998, p. 22)

Desde a época colonial, eram bem vindas as opiniões predominantes na Europa sobre atendimento à infância, contudo, já se faziam presentes as diferenças no atendimento destinado a crianças brancas e negras. Este fato marcou o início da nossa histórica do atendimento à criança com o crivo da desigualdade (FARIAS, 2005). Os filhos de escravos, chamados de crias e moleques, seguiam para o trabalho a partir de cinco anos, devendo aprender algum ofício. As crianças brancas da casa grande, nomeadas de meninos, filhos de família, quase sempre eram cuidadas por amas, recebiam instrução jesuítica a partir dos seis anos, aprendiam as primeiras letras com professores particulares, usavam trajes adultos e sua educação se apoiava nos castigos corporais. Aspectos representativos da divisão de classes e das diferenças sócio-econômicas que caracterizavam o tipo de atendimento a elas dispensado.

Nesse período, foi criada a primeira Santa Casa de Misericórdia, em Salvador, no ano de 1726 (Rio de Janeiro, 1738; Recife, 1789 e em São Paulo, 1825). Eram instituições católicas de cunho caritativo que receberam crianças abandonadas, essencialmente filhos 
de escravas, em um dispositivo denominado "roda" ${ }^{2}$, conhecido como a Roda dos Expostos (DEL PRIORI, 2004). Este era um local público que legitimava o desamparo anônimo de crianças indesejadas, nomeadas de "os expostos", e onde eram colocadas, em vez de as pessoas as deixarem nas ruas, lixeiras, portas de igrejas ou casas. (RIZZINI; RIZZINI, 2004)

Para a sociedade da época, a Roda dos Expostos, na opinião de Marcilio (1999, p. 72), teve um papel importante no atendimento às crianças abandonadas por distintas razões:

A roda foi instituída para garantir o anonimato do expositor evitando-se na ausência daquela instituição e na crença de todas as épocas, o mal maior, que seria o aborto e o infanticídio. Além disso, a roda poderia servir para defender a honra das famílias cujas filhas teriam engravidado fora do casamento. Alguns autores atuais estão convencidos de que a roda serviu também de subterfúgio para se regular o tamanho das famílias, dado que na época não havia métodos eficazes de controle da natalidade.

No entanto, no séc. XVIII era comum a morte de muitas crianças abandonadas na "roda" devido à ausência de condições mínimas de higiene e saneamento na Santa Casa, sendo que as sobreviventes eram entregues a "criadeiras externas". Segundo Farias (2005), nesta época, as Câmaras Municipais do Brasil designavam uma verba ao acolhimento de crianças negras, mestiças ou brancas abandonadas, as chamadas crianças enjeitadas. O pagamento de amas-de-leite e criadoras ocorria para que mulheres/famílias as criassem até os nove anos. As crianças indígenas ainda eram alvo do projeto educativo de catequização, como forma de garantir a civilização dos povos indígenas. Em suma, a essência da atenção dispensada à criança e à infância nesta etapa da história se deu sob a forma de caridade, proveniente dos religiosos católicos e de grupos de leigos

\footnotetext{
${ }^{2}$ A roda tem o formato de cilindro cuja superfície lateral é aberta em um dos lados e que gira em torno de um eixo vertical. O lado fechado fica voltado para a rua. Uma espécie de campainha exterior era colocada nas proximidades para que a pessoa que desejasse entregar um recém-nascido pudesse acioná-la avisando à pessoa de plantão. O recém-nascido era levado para o interior da Santa Casa de Misericórdia pelo mecanismo de fazer o cilindro girar em torno de si mesmo até virar para fora o seu lado aberto, e a criança ali ser depositada. Em seguida, continuando o movimento até girar o cilindro até sua parte aberta se voltar pra dentro novamente. Para saber mais, consultar DEL PRIORE, Mary. História das crianças no Brasil. São Paulo: Contexto, 2004.
} 
filantrópicos. O Estado não teve participação na assistência, não criou instituições e nem regulamentou as existentes (DEL PRIORI, 2004; KUHLMANN, 1998).

A partir do século XVIII, os asilos ${ }^{3}$ foram instalados no Brasil e atendiam às crianças nascidas de relacionamentos ilegítimos entre senhores e escravas ou, aos filhos das escravas, para que estas pudessem ser alugadas como mães de leite.

No século XIX, o mundo atravessava transformações significativas, principalmente nos domínios econômicos e sociais que alteraram o cenário mundial. No mesmo período, o Brasil viveu importantes mudanças político-sociais, iniciadas com a vinda da Família Real para o Brasil (1808), que promoveu a abertura dos portos às nações amigas e a criação de cursos destinados à qualificação dos habitantes com base em necessidades brasileiras, provendo, de certo modo, o processo de rompimento com o ensino jesuítico do Brasil colonial.

No contexto político e econômico do início do século XIX, o Brasil começou a viver um período de impasse em relação à educação das crianças menores de sete anos, assinalado por acontecimentos em dois campos: um deles tem a ver com a partida da Família Real para Portugal, seguida da regência do Brasil e pela proclamação da independência da coroa portuguesa, por D. Pedro, em 1822. O outro campo apresentava vários aspectos: o momento econômico do início do século, de expansão da lavoura cafeeira e o crescimento capitalista interno localizado nas cidades; a criação da primeira

\footnotetext{
${ }^{3}$ Em 1826, na França, foram também criadas as salas de asilo (depois nomeadas de escolas maternais), cujas finalidades de atendimento se organizavam em torno de cuidados, educação moral e intelectual às crianças de três a seis anos de idade, ao passo que as creches passaram a existir para atender às crianças de até três anos. (KUHLMANN, 2001). Já em Portugal, desde sua fundação, em 1834, as casas de asilo da infância funcionavam com função pedagógica, no sentido instrucional, além de oferecer os cuidados com a alimentação e o corpo. Nas repúblicas italianas e na Holanda, igualmente, há registros de instituições semelhantes para diferentes faixas etárias no decorrer da primeira metade do século XIX. No entanto, as creches, as salas de asilo, depois chamadas escolas maternais, e os jardins-de-infância de Froebel, foram os mais disseminados. No ano de 1848, surgiram na França as chamadas escolas maternais com a intenção de substituir o termo sala de asilo e alterar o tipo de atendimento para as crianças pobres, as quais eram expostas a um atendimento precário e a cansativos exercícios de escrita. A orientação das escolas maternais era de caráter educativo e priorizava o desenvolvimento integral das crianças; contrariamente, as salas de asilo existiam, predominantemente, para guardar um grande número de crianças (OLIVEIRA, 2011). A escola maternal francesa deveria efetuar a proposta de Froebel por meio de um ambiente agradável e de ensino, mas a tradição do termo sala de asilo continuou a ser do uso cotidiano e o modo de atendimento não mudou. $O$ preconceito do governo francês em relação às instituições que atendiam crianças pobres e abandonadas o motivou a propor a alteração da denominação da sala de asilo. Seu objetivo foi tornar a escola maternal mais acolhedora e bela repelindo a ideia de miséria e desamparo, com a adoção da nova designação (KISHIMOTO, 1988).
} 
escola oficial do Rio de Janeiro (1880); a chegada de imigrantes aos milhares à procura de trabalho assalariado, a assinatura pela Princesa Isabel da lei que aboliu o sistema escravo no país em 1888. No entanto, com a lei do ventre livre e a pobreza das famílias, muitas abandonavam seus recém-nascidos ou os deixavam na "Roda dos Expostos". Cabe lembrar que, nesta época, as crianças menores de sete anos eram cuidadas e ensinadas pela mãe.

Assim, a partir da metade do século XIX, o índice de mortalidade das crianças desamparadas era elevado, fato que incitou os abolicionistas e higienistas a desaprovarem a prática da roda e as amas. O atendimento educacional ainda não existia para os filhos dos pobres. Seu destino era se tornarem cidadãos úteis e produtivos na lavoura, enquanto os filhos da elite eram instruídos por professores particulares. É interessante assinalar que, para as mães das classes abastadas, era desde esta época exaltado o direito à maternidade, sendo que, para as mulheres pobres, cabia o mundo do trabalho e a incerteza sobre onde e com quem deixar seus filhos, fossem elas escravas ou não (RIZZINI; RIZZINI, 2004; KUHLMANN JUNIOR, 1998). A apologia pelo médico dos expostos e por alguns grupos para adoção das creches nos moldes franceses para abrigar crianças pobres e abandonadas tomavam corpo nesse período no bojo de um sentimento de urgência em criar espaços para a "guarda" destas crianças. O projeto político de construção de um Brasil moderno vicejava no âmbito das idéias liberais do final do século XIX. Nesse contexto, os princípios do movimento da Escola Nova foram acolhidos pelos intelectuais, sob a ideia de que o moderno significaria progresso. Nesta perspectiva, as instituições de Educação Infantil surgiam como uma proposta moderna. Kuhlmann (1998, p. 78) afirma que em relação às crianças pobres,

[...] a creche, para as crianças de zero a três anos, foi vista como muito mais do que um aperfeiçoamento das Casas de Expostos, que recebiam as crianças abandonadas; pelo contrário, foi apresentada em substituição ou oposição a estas, para que as mães não abandonassem suas crianças.

Na verdade, no contexto histórico em discussão, nos dizeres de Kuhlmann Junior. (1999, p. 73) havia, sim, uma distinção entre creche e pré-escola. 
O jardim de infância, criado por Froebel, seria a instituição educativa por excelência, enquanto a creche e as escolas maternais - ou qualquer outro nome dado à instituição com características semelhantes às Salles d' asile francesa - seriam assistências e não educariam para a emancipação, mas à subordinação.

As creches no Brasil surgiram, neste cenário, para minimizar os problemas sociais decorrentes do estado de miséria de mulheres e crianças. Ao contrário dos países da Europa, em que a expansão das creches derivava da necessidade do atendimento às crianças cujas mães foram recrutadas como mão de obra para as fábricas, conforme esclarece Didonet (2001, p. 12):

As referências históricas da creche são unânimes em afirmar que ela foi criada para cuidar das crianças pequenas, cujas mães saíam para o trabalho. Está, portanto, historicamente vinculada ao trabalho extradomiciliar da mulher. Sua origem, na sociedade ocidental, está no trinômio mulher-trabalho-criança.

Em algumas cidades do país, as primeiras creches substituíram a Casa dos Expostos, com seu caráter assistencial e de guarda voltado ao atendimento das crianças e famílias empobrecidas. Apresentavam elementos que marcaram por longos anos a história da creche na sociedade, como o seu caráter caridoso, a especificidade da faixa etária, a qualidade das mães como pobres e trabalhadoras, conforme apresentado no relato do jornal $A$ mãi de família. As instituições de assistência à infância eram vistas com preconceitos, pois eram lugares de crianças pobres e carentes marcados pelo cuidado com o corpo, saúde e alimentação.

Na vigésima sessão pública da Sociedade de Creche em Paris, em 13 de maio de 1877, o imperador e a imperatriz do Brasil estavam presentes. O Statut des Crèches traz no seu artigo primeiro a definição de onde foi tirada a versão brasileira: "Uma associação caritativa é constituída entre indivíduos caridosos que almejam instituir uma creche para crianças pobres menores de dois anos, cujas mães trabalham fora do seu domicilio e tenham uma boa conduta." É assim que é reproduzida, do regulamento da creche francesa para o Brasil, a intenção de ofertar assistência por pessoas caridosas ou da 
filantropia às mães de boa conduta com filhos menores de dois anos de idade que trabalhavam fora do seu contexto doméstico.

No Brasil, o periódico A Mãi de Família, jornal científico, literário e ilustrado publicou, a partir de janeiro de 1879, uma sequência de cinco artigos sobre creche (o primeiro deles teve o título A creche - asilo para a primeira infância), escritos pelo médico dos expostos, o Dr. K. Vinelli. No artigo, o médico fez referência à creche para resolver o problema das senhoras burguesas, as quais tinham em suas casas mães escravas. A originalidade de sua ideia foi separar as crianças escravas de suas mães e levá-las para as creches. Assim o Dr. Vinelli explicou a visão e finalidade da creche: "A creche é um estabelecimento de beneficência que tem por fim receber todos os dias úteis e durante as horas de trabalho, as crianças de dois anos de idade para baixo, cujas mães são pobres, de boa conduta e trabalham fora de seu domicilio." (VINELLI, 1879 apud CIVILETTI, 1991, p. 36).

Nesse período, encontra-se a gênese das concepções iniciais sobre a creche no Brasil que adota da França (sua primeira crèche foi implantada por Marbeau em 1844) a finalidade e o modo de funcionamento da creche, bem como a terminologia salle d'asile $e$ creche, esta última com sentido de manjedoura. Observe que o sentido atribuído à creche institui uma separação entre classes sociais, na medida em que se propõe espaço de atenção, exclusivamente, às crianças pobres com a finalidade de liberar a mão de obra feminina (KUHLMANN JUNIOR, 1998; KRAMER, 1995). De acordo com Didonet (2001, p. 12):

Os primeiros nomes dessa instituição são reveladores do seu propósito: garderie, na França; asili, na Itália; écoles gardiennes, na Bélgica. Até hoje, guardería é a expressão usada em vários países latino-americanos para referir-se à instituição que atende às crianças menos de 3 anos. "Guarda da criança" também foi a expressão que traduzia a intenção nos primórdios dessa instituição no Brasil.

Resumindo o que tratamos, por volta da época do descobrimento do Brasil, as crianças viveram um novo momento, com o afastamento da convivência familiar por meio da tutela da criança órfã e indígena, nomeadamente pela Igreja. As crianças indígenas foram tratadas pelos colonizadores como indigentes e sem função, visão que determinou a ausência de políticas sociais de atendimentos a estas. No período colonial, por sua vez, 
as peculiaridades em relação à atenção à infância brasileira foram cunhadas no âmbito de fatos como: o legado dos padrões europeus de atendimento à criança; a adoção da roda dos expostos pelo movimento católico para abrigar crianças abandonadas; a instituição pelo governo do pagamento de amas-de-leite e criadoras para atender as crianças abandonadas na "roda"; o alto índice de mortalidade infantil devido às condições sanitárias precárias; as crianças brancas ricas do sexo masculino frequentavam os colégios religiosos para aprender latim e bons hábitos, e as negras eram direcionadas ao trabalho escravo; a adoção dos castigos corporais como maneira de educar as crianças, consideradas incompetentes e imperfeitas. Nesta época, a concepção de infância se firmava diferentemente, conforme a condição social e econômica da criança, porém, associada ao trabalho, no caso da criança pobre, fosse ela escrava, órfã ou recrutada pela coroa portuguesa e trazida nas embarcações.

No período que se denomina de Brasil independente (1822 até 1889), a sociedade se deparou com um crescente aumento da criminalidade causado pelo aumento das populações que vinham do campo para as cidades e pela economia que trouxe queda da qualidade de vida. A criança desvalida foi ficando mais visível. Neste momento histórico, os adultos e crianças infratoras eram conduzidos ao mesmo local, sendo a criança vista como um ser marginal, a exemplo da constituição de 1824, que não dispensava atenção especial à criança e que necessitaria ser submetida ao controle policial.

Somente em 13 de fevereiro de 1861 foi fundado na Casa de Correção da Corte, o Instituto de Menores Artesãos encarregado de abrigar trezentos menores. Aqueles que cometiam algum delito, os reputados de má índole ou aqueles cujas famílias não davam uma educação considerada apropriada, eram reclusos para receberem educação moral e religiosa. Os menores aprendiam uma profissão, além de música, desenho e estudo (BRASIL, 1861). Na verdade, o Instituto de Menores tinha a finalidade de disciplinar os corpos por meio do uso de castigos corporais, a fim de tornar a mente obediente. $O$ Estado tutelava a criança pobre como se fosse delinquente e passava a ensinar-lhe ofícios. Com o passar do tempo, eram encaminhadas a essa instituição todas as crianças em situação de rua, sendo elas infratoras ou não. 


\section{A atenção à criança no Brasil de 1874 a 1889}

No Brasil ${ }^{4}$, a infância começa a ganhar reconhecimento em 1875, quando é fundado pelo médico José Menezes Vieira e sua esposa Carlota de Menezes Vieira, no Rio de Janeiro, o primeiro jardim de infância privado reservado aos filhos do sexo masculino da emergente classe média industrial. A metodologia utilizada incluía o método intuitivo para o desenvolvimento da percepção direta e experimental das crianças, e seguia o ideário de Pestalozzi e as atividades sugeridas por Froebel e Mme. Pape-Carpantier 5 . Apesar de sua escola atender a alta aristocracia, Menezes defendia que os jardins de infância deveriam dar assistência às crianças negras libertas pelo ventre livre e às com pouca condição econômica.

Assim, nesse período, desenvolve-se o setor privado da educação pré-escolar, ou seja, os primeiros jardins de infância particulares, dedicados a atender, quase que em sua maioria, a alta aristocracia da época com função central de cuidar, higienizar, educar a criança, transmitir os valores sociais e morais da elite dominante. De acordo com Kuhlmann Jr. (1998, p. 82),

[...] o setor privado da educação pré-escolar, voltado para as elites, com os jardins-de-infância, de orientação froebeliana, teve como principais expoentes, no Rio de Janeiro, o do Colégio Menezes Vieira, fundado em 1875; e em São Paulo, o da Escola Americana, de 1877. No setor público, o jardim-de-infância anexo à escola normal Caetano de Campos, de 1896, (...), atendia aos filhos da burguesia paulistana.

O jardim de infância aspirava cumprir o papel de moralizador da cultura, transmitindo às crianças os mesmos padrões ostentados na França e na Bélgica. Seria ele "um antídoto contra as ameaçadoras práticas que tentavam solidariedade com os setores explorados de nossa sociedade" (KUHLMANN JUNIOR, 2000, p. 476). Por outro lado, a

\footnotetext{
${ }^{4}$ Partes do presente texto compõem a dissertação de mestrado de minha autoria: GUIMARÃES, Célia Maria. Leitura e escrita na pré-escola - o processo de ensino da leitura e escrita: idéias, concepções e influencias na prática educacional dos professores da pré-escola municipal de Presidente Prudente, SP. 1995 (Mestrado em Educação) - Programa de Pós-Graduação em Educação, Faculdade de Filosofia e Ciências - Universidade Estadual Paulista - Presidente Prudente.

${ }^{5}$ Marie Pape-Carpantier (1815-1878) foi professora das primeiras salas de asilo, na França. Criou a caixa de Lições de Coisas - um instrumento para as lições sobre origem, a história e fabricação das principais coisas de uso geral na vida cotidiana.
} 
creche se destinava às crianças privadas dos cuidados maternos devido ao trabalho da mãe, com objetivo central de evitar o abandono destas por seus responsáveis.

Segundo Kramer (1995, p. 50) “[...] faltava, de maneira geral, interesse da administração pública pelas condições da criança brasileira, principalmente a pobre.” Por isso, somente a partir de 1874, há registros em documentos brasileiros propondo ações para o cuidado da criança. Voltados para as elites da época, são fundados em 1877, a Escola Americana e, em 1896, embora público, o Jardim de Infância da Escola Caetano de Campos, em São Paulo, que atendia aos filhos da burguesia paulistana. Os dois espaços eram reservados às famílias ricas. A alta sociedade diferenciava os jardins de infância dos asilos e das creches das classes pobres, lançando mão, para este fim, de propostas pedagógicas inspiradas no ideário de Froebel (KRAMER, 2003; KUHLMANN JUNIOR, 1991; 1998).

Kishimoto (1988) adverte que nos documentos da criação dos jardins de infância, estes espaços foram considerados lugares da pedagogia voltada às brincadeiras; o objetivo era o de forjar o desenvolvimento integral das crianças (físico, moral e intelectual), além de realizar a transição da família para a escola, atendendo crianças de quatro a seis ou sete anos durante meio período. Por isso, não competiria ao Estado financiar um local de brincadeiras para a infância rica, o que explica que inicialmente os jardins de infância eram considerados por diversos educadores e políticos um luxo. Kishimoto (1988, p. 33) refere que nos documentos do Colégio Menezes Vieira, por exemplo, não era oferecido o ensino da leitura e da escrita, mas se propunha a “aproveitar as variadas e expressivas manifestações da atividade infantil”, embora as tarefas voltadas para instrução e dirigidas pela professora fossem constantes. Essa pratica educativa deixava de lado a proposta original de Froebel no lugar de um suposto trabalho para o desenvolvimento do intelecto infantil.

Kuhlmann Junior (2001) esclarece que os chamados jardins de infância, direcionados às crianças da classe burguesa, já apresentavam característica mais educacional, o que os diferenciava da função primordial de guarda reservada às creches para as classes populares. O termo asilo para crianças designava as instituições com a função de guarda da criança pobre no período diurno, com o objetivo de evitar o seu abandono. Havia ainda uma diferença entre os asilos e as Casas de Expostos e as Escolas 
de Aprendizes de Marinheiros, pois estas instituições tinham a função de abrigo, destinadas às crianças já abandonadas.

\begin{abstract}
A preocupação daqueles que se vinculavam às instituições pré-escolares privadas brasileiras era com o desenvolvimento de suas próprias escolas. Nota-se, entre eles, a utilização do termo pedagógico como uma estratégia de propaganda mercadológica para atrair as famílias abastadas, como uma contribuição do jardim-de-infância para os ricos, que não poderia ser confundido com os asilos e creches para pobres. (KUHLMANN JUNIOR, 2001, p. 83-84)
\end{abstract}

Segundo o autor, o que distingue as diferentes instituições é a sua destinação social, pois "O filho da senhora estudava no "jardim"; o da serviçal, na creche". A proveniência social e não a institucional das instituições é a responsável pela origem dos diferentes objetivos educacionais presentes nas propostas de instituições e na história do atendimento da infância. No entanto, Kuhlman Jr. (1998) observa que historicamente todas as instituições dedicadas à infância possuem algum tipo de projeto educacional, contendo finalidades emancipatórias ou de subordinação, não importando sua denominação ou programa pedagógico.

Na década de 70 do século XIX, sobreveio a Reforma Leôncio de Carvalho, por meio do Decreto n. 7.247 de 19 de abril de 1879 que, dentre várias reformas, determinou a criação dos jardins de infância em cada distrito do município da Corte voltados à educação de crianças de três a sete anos de idade. Porém, previa recursos exclusivamente à educação de crianças dos sete aos quatorze anos. Este descaso será visto em outros momentos da história do atendimento a infância e à criança no Brasil.

A Exposição Pedagógica de 1883, no Rio de Janeiro, evento que substituiu o Congresso da Instrução, não realizado, legitimava os interesses privados da educação pré-escolar, apesar de referir-se à necessidade de implantar jardins de infância para atender aos menos favorecidos. Durante o evento, foi designado um comitê para cuidar das demandas dos jardins de infância, ainda que fossem interpretados como "locais perigosos", pois se acreditava que poderiam ocasionar vários traumas às crianças causados pela escolaridade precoce e a retirada da criança do ambiente familiar, podendo suscitar reflexos negativos na aprendizagem no ensino regular. A partir da análise das 
exposições internacionais realizadas entre 1850-1920, Kuhlmann Jr. (2001, p. 78) concluiu que "[...] creches, salas de asilo, escolas maternais e jardins de infância sempre foram incluídas como instituições de educação infantil, porém o que as diferenciava eram a origem e a faixa etária do público social a que se destinavam".

Em síntese, a tutela da criança órfã pelo Estado, os castigos corporais e o alto índice de mortalidade infantil prosseguem presentes como características do atendimento infantil do período. Novas abordagens da infância resultam no Instituto para menores infratores, na tutela da criança pobre como criminosa, no ensino de ofícios e na escola de aprendizes de marinheiro, todos destinados às crianças pobres. Os jardins de infância tinham público definido: a criança rica.

A abolição da escravidão no Brasil, em 1888, não instituiu o afastamento da submissão das crianças através do trabalho infantil, prosseguiu como instrumento de controle social da infância e de reprodução social das classes. Dadas às circunstâncias históricas da proclamação da República, da abolição da escravatura e da imigração de mão de obra européia, dentre outras conjunturas, um número expressivo de crianças viviam na rua, o que fez a questão da criança ser percebida como problema social. Por causa da preocupação crescente com a situação da criança e com o futuro do Brasil República, ao longo do século XIX, houve uma substituição das ações religiosas com caráter de caridade pela assistência de cunho social. O contexto político e econômico do final deste século originou um interesse do Estado em cuidar e controlar a infância com finalidade de construir um futuro promissor para o país (RIZZINI; RIZZINI, 2004). Assim, a nova mentalidade sobre a criança como futuro da nação agencia o surgimento da pediatria no país entre 1874 e 1889. Os profissionais dessa especialidade médica treinavam as famílias nos cuidados para com a saúde e higiene da criança. Os primeiros anos de vida já eram reconhecidos como uma etapa importante, mas o objetivo era moldar a criança, sob a alegação de defesa da sociedade (RIZZINI, 1997). 


\section{A atenção à criança no Brasil de 1889 até 1930}

Do ano de 1889 a 1930, encontra-se o período do Brasil República - a chamada República Velha. A economia e a política ficaram sob o comando das elites agrárias mineiras, paulista e cariocas. O país se despontou como respeitado exportador de café e a indústria cresceu, mas os problemas sociais herdados do Império se intensificaram pelo território brasileiro, a exemplo das taxas de mortalidade infantil que cresceram muito. Contudo, nesta etapa houve um papel mais representativo da administração pública com ações voltadas para a criança.

No decorrer das duas décadas iniciais do século $X X$, surgem as primeiras instituições pré-escolares assistencialistas no Brasil, além disso, “[...] a recomendação da criação de creches junto às indústrias ocorria com freqüência nos congressos que abordavam a assistência à infância” (KUHLMANN JUNIOR., 1998, p. 85).

Entre o final do século XIX e início do XX incide o "movimento higienista" que almejava cuidar da população por meio da educação e ensinamentos de novos hábitos (GÓIS JUNIOR, 2002). Segundo o autor, os chamados higienistas eram representados por diferentes segmentos da sociedade e dos meios políticos cuja finalidade comum era aperfeiçoar a saúde da população e oferecer assistência à infância, incentivados pela compreensão de que a falta de educação e saúde do povo causaria o atraso do Brasil em relação à Europa.

A representação de que as crianças seriam uma ameaça ao futuro de uma nação promissora justificava o caráter preventivo e de recuperação das crianças pobres presente nas instituições encarregadas dos seus cuidados. A assistência não privilegiava o que na época foi caracterizado como menor, menor abandonado e menor delinquente porque, de fato, a criança em si mesma não se encontrava no centro das preocupações. A diferenciação entre menor e criança deixou sua marca na infância dos vários segmentos sociais no decorrer do século XX, e é desfeita em 1988, com a promulgação da Constituição brasileira (RIZZINI; RIZZINI, 2004).

Alvim e Valladares (1988) argumentam sobre quão significativa foi a adoção da terminologia Menor para a construção de uma imagem da criança pobre brasileira como abandonada e delinquente em potencial. A nomenclatura utilizada na categorização da 
infância pobre brasileira atravessou uma longa trajetória desde as qualificações de “expostos”, “órfãos”, “a infância desvalida”, "os petizes”, “os capoeiras” ou "vadios” até o termo jurídico "menores", que evoca, principalmente a ideia de "irregularidade".

O problema dos delinquentes era tratado com o internamento em instituições de correção em conformidade com o Código Penal de 1890, regulamentado em seguida pelo primeiro código brasileiro para assistência e proteção à Infância e Adolescência, o Código de Menores de 1927 (Decreto 17.943-A, de 12-10-1927). Assim sendo, por volta de 1927, a criança se torna objeto de preocupações jurídicas no país e o Estado elabora sua primeira política pública para a infância pobre, com a implantação do referido Código que, por sua vez, estimulou a criação dos instrumentos jurídicos que passaram a apoiar as instituições com uma abordagem predominantemente médico-jurídica por intermédio do Poder Judiciário.

Em 1897, foi inaugurado, em São Paulo, o edifício do Jardim da Infância, com o propósito de educar as crianças da classe dominante, entre quatro e sete anos de idade. O Jardim da Infância ou Kindergarten ${ }^{6}$ se inspirava nas ideias do filósofo alemão Friedrich Wilhem August Froebel e tinha como objetivo e prática educar os sentidos das crianças e despertar o divino existente na essência da alma humana. Com esse intuito, as professoras, que eram nomeadas como "jardineiras", deveriam ser especialistas para saberem empregar jogos, cantos, danças, marchas e pinturas como estímulos à aprendizagem infantil. A prática escolar do século XIX recebeu muita influência do método froebeliano para a primeira infância e com isso fixou a imagem da criança como idade criativa. O evento da chegada dos jardins de Infância no Brasil com este caráter institui duas modalidades de atendimento às crianças de zero a seis anos no Brasil: os jardins-de-infância para crianças da elite e as creches ou escolas maternais que ofereciam assistência e educavam as crianças com menos recursos financeiros.

[...] o que se pode notar, do que foi dito até aqui, é que as creches e préescolas surgiram a partir de mudanças econômicas, políticas e sociais que ocorreram na sociedade: pela incorporação das mulheres à força de trabalho assalariado, na organização das famílias, num novo papel da mulher, numa nova relação entre os sexos, para citar apenas as mais

\footnotetext{
${ }^{6}$ Este termo tem origem nos ideais de Froebel que compara o crescimento das crianças ao das plantas e o papel das professoras ao de jardineiras.
} 
evidentes. Mas, também, por razões que se identificam com um conjunto de ideias novas sobre a infância, sobre o papel da criança na sociedade e de como torná-la, através da educação, um indivíduo produtivo e ajustado às exigências desse conjunto social. (BUJES, 2001, p. 15)

A partir de 1899 são verificados progressos, impulsionados por grupos interessados em envolver esferas governamentais com o problema das crianças, nos campos da higiene infantil, médico e escolar. No mesmo período, foram fundadas várias instituições, por iniciativa particular, e leis foram promulgadas, evidenciando preocupação com o problema da criança. Mas, as autoridades governamentais continuavam inertes em termos de iniciativas objetivas em favor da criança. Deste modo, em 1899, o médico Arthur Moncorvo Filho liderou a fundação do Instituto de Proteção e Assistência à Infância do Brasil (IPAIB), com sede no Rio de Janeiro (em 1929, já havia vinte filiais pelo país, onze creches, sendo uma delas em Curitiba), com objetivo de criar creches e jardins de infância para atender crianças menores de oito anos de idade, entre outros fins. Sua finalidade básica eram os serviços de puericultura e creche, com ênfase na ginecologia, distribuição de leite, consulta a lactantes, vacinação, etc.

Neste mesmo ano foi fundada, pela fábrica de tecidos Corcovado, a creche da Companhia de Fiação e Tecidos Corcovado, no Rio de Janeiro, com caráter de guarda e assistência aos filhos das mães operárias. Esta foi a primeira creche brasileira, que se tem registro, dedicada aos filhos de operários. Kuhlmann Jr. (1996) considera 1899 como o ano do surgimento de creches que passaram a ocupar o cenário da assistência à infância brasileira. Nos congressos em que se abordava a assistência à infância, as recomendações para a criação de creches junto às indústrias e de entidades assistenciais tomavam vulto (KUHLMANN JUNIOR, 1991). De outro lado, nesta época, os jardins de infância eram considerados educativos e tornaram-se a forma de atendimento aos pobres.

Sendo assim, por volta do final do século XIX, no lugar de uma política educacional, havia uma política jurídico-assistencial de atenção à criança. O Estado se preocupava com as crianças consideradas perigosas para a coletividade e, aquelas que tinham casa e família, permaneciam sob os cuidados da própria família.

O início do século XX no Brasil apresentava um panorama de problemas originados pela expansão caótica das cidades. A chamada medicina social fazia a intervenção médica 
por meio de movimentos higienistas com a intenção de desempenhar uma maior vigilância e maior controle sobre a população, particularmente as crianças, intervindo para o seu bem-estar físico e moral. Contudo, não havia conhecimentos sobre particularidades infantis como alimentação, forma de pensar específica etc. Foi um período caracterizado pelo extraordinário aumento das entidades assistenciais, a maioria ligada à Igreja Católica para o atendimento de crianças órfãs, para a atenção aos abandonados e aos delinquentes. Deste modo, a atenção à criança aconteceu de um lado, com base no ensinamento moral e, de outro, com a preparação para o trabalho.

Durante as duas décadas iniciais do século XX, implantaram-se as primeiras instituições pré-escolares assistencialistas no Brasil e as entidades assistenciais fundaram creches. Em 1908, é fundada a "primeira creche popular cientificamente dirigida", para crianças de até dois anos de idade, filhas de operários, mas a maior parte das práticas dedicadas às crianças de zero a seis anos era de caráter médico.

Neste contexto, foi criada, em 1908, a primeira escola maternal pela educadora Anália Franco, em São Paulo, para atender os filhos de operárias das fábricas paulistanas. As crianças ingressavam nessas instituições com dois anos de idade e permaneciam até os cinco anos, dilatado posteriormente até os 12 anos de idade. Essas escolas deveriam ser diferentes dos asilos e das creches, pois em seus documentos definiam objetivos pedagógicos e assistenciais de alimentação e proteção. Nas propostas descreviam a aliança entre a assistência e o trabalho pedagógico. Na prática, os trabalhos eram muitas vezes conduzidos por leigos, pois havia falta de professores capacitados. Por isso, neste caso, prevaleceu o mesmo atendimento dos asilos e as crianças ainda tinham que enfrentar o ensino mnemônico de conteúdos de Gramática, Aritmética e Geometria (KISHIMOTO, 1988).

Em 1909, após 30 anos de promulgação do decreto n. 7247, de 1879, foi inaugurado no Rio de Janeiro o primeiro jardim de infância público, o Jardim de Infância Campos Salles, voltado para escolarização de meninos e meninas entre quatro e sete anos.

Em 1919, foi criado o Departamento da Criança no Brasil, com o apoio do Instituto de Proteção à Infância sob a indicação de realizar diferentes tarefas como o histórico sobre a situação da proteção à infância no Brasil; fomentar iniciativas de amparo à criança 
e à mulher grávida pobre; publicar boletins; divulgar conhecimentos; promover congressos; convergir para o bom emprego das leis de amparo à criança; uniformizar as estatísticas brasileiras sobre mortalidade infantil, cuja responsabilidade caberia ao Estado, mas que na realidade foi mantido por doações. Kramer (1995, p. 53) expõe que “[...] as autoridades governamentais que haviam permanecido inertes em termos de realizações objetivas a favor da criança pobre e abandonada começavam a proclamar a necessidade de seu atendimento". Foi a primeira iniciativa de alcance nacional, contudo, o seu caráter era médico-assistencialista e o compromisso com educação das crianças ainda era inexistente conforme Kramer ( 1995; 2003).

Kuhlmann Jr. (2004) ilustra que no curso do período de 1899 a 1922, as instituições assistencialistas originaram-se da preocupação com a mortalidade infantil, motivada pela construção de uma cidadania que satisfazia os interesses das classes dominantes. Elas traziam objetivos de modernização contendo princípios filosóficos liberais, contrários à concepção de caridade e de piedade.

A educação não seria necessariamente sinônimo de emancipação. O fato de essas instituições carregarem em suas estruturas a destinação a uma parcela social, a pobreza, já representa uma concepção educacional. A pedagogia das instituições educacionais para os pobres é uma pedagogia da submissão, uma educação assistencialista marcada pela arrogância que humilha para depois oferecer o atendimento como dádiva, como favor aos poucos selecionados para receber. Uma educação que parte de uma concepção preconceituosa da pobreza, por meio de um atendimento de baixa qualidade, pretende preparar os atendidos para permanecer no lugar social a que estariam destinados. (KUHLMANN JUNIOR., 2004, p.182)

No ano de 1918, em decorrência das pressões dos movimentos operários, foi criada a primeira creche no estado de São Paulo, numa vila operária da Companhia Nacional de Tecidos e Jutas. Neste período, a expansão industrial é uma realidade paulistana com consequente aumento da utilização da mão de obra feminina nas fábricas. As creches e albergues proliferam nas redondezas das fábricas, favorecidas pela falta de fiscalização e pela necessidade de pais e mães "depositarem" seus filhos a um baixo pagamento em lugares... 
[...] sem as mínimas condições para atendimento à criança em idade préescolar [com menos de cinco anos]. Conhecidas por absorver apenas funções de guarda de crianças não merecem a atenção do governo, que se nega a fiscalizar estabelecimentos mantidos pela caridade ou por indivíduos dispostos a explorar comercialmente tais casas. (KISHIMOTO, 1988, p. 26)

Na década de 1920, a classe operária de imigrantes no Brasil iniciava várias reivindicações trabalhistas, dentre elas, alterações nas longas jornadas de trabalho, melhoria salarial e a existência de locais para a guarda de seus filhos durante o trabalho. Para conter a agitação dos operários os empresários criaram "vilas operárias, clubes esportivos e também algumas creches e escolas maternais para os filhos dos operários em cidades como Rio de Janeiro, São Paulo e Minas Gerais" (OLIVEIRA, 2005, p. 96).

O crescimento da industrialização no país, a constituição de uma nova elite burguesa no lugar da cafeeira, o agravamento do estado de miséria de um grande número de pessoas, a inserção da mulher nas fábricas, o operário imigrante europeu e o início dos conflitos nas relações patrões-operariado deflagraram um processo de protestos sociais por creches. Embora fosse insuficiente a ampliação do atendimento em creches nesse período, ela se vinculava ao "poder" da crescente organização popular na reivindicação dos direitos sociais, o que terá uma dimensão maior na década de 1980 . Kuhlmann Jr. (1998) explica que a concessão das creches pelos patrões em resposta às reivindicações dos operários por melhores condições de vida se dava como favor, distanciando-se do caráter de dever social.

Em 1923, houve a primeira regulamentação do trabalho da mulher com a proposta de instalação de creches e salas de amamentação próximas aos postos de trabalho. Nesse período, a função de guarda das crianças caracterizava todos os tipos existentes de creche para pobres. Seu funcionamento seguia o modelo hospitalar, geralmente sob os cuidados de profissionais da área da saúde conforme a palavras de Kuhlmann Jr. (2001, p. 60):

[...] criaram-se leis e propagaram-se instituições sociais nas áreas da saúde pública, do direito da família, das relações de trabalho, da educação. [...] são iniciativas que expressam uma concepção assistencial a que denominamos "assistência científica" por se sustentar na fé, no progresso e na ciência característica daquela época. 
Podemos dizer que desde o final do século XIX até o início do século $X X, 0$ atendimento nas creches permanecia vinculado ao campo médico-sanitarista e ambicionava nutrir as crianças, promover a saúde e disseminar normas rígidas de higiene. Esta visão associou a pobreza à falta de conhecimentos de puericultura e mascarou qualquer relação com as questões econômicas e políticas do país naquele período. Nos anos que antecederam a década de 1920, a iniciativa particular oferecia a atenção à infância sob o apoio do Estado, sem que existisse, de sua parte, a proposição de ações políticas.

Em 1922, no âmbito do $1^{\circ}$ Congresso de Proteção à infância, houve a solicitação para a ação das autoridades governamentais. Em 19 de novembro de 1930, o Decreto $\mathrm{n}$. 10.402 criou o Ministério da Educação e de Saúde Pública. Deste modo, naquele ano, o atendimento pré-escolar já contava com a participação direta da esfera pública. Assim ocorreu em consequência de reformas jurídico-educacionais que pretendiam atender à nova ordem legal da educação: pública, gratuita, e para todos, tanto quanto acatar à crescente pressão por direitos trabalhistas em decorrência das lutas sindicais da então nova classe trabalhista brasileira. Ainda em 1922, no Rio de Janeiro, houve o Primeiro Congresso Brasileiro de Proteção à Infância.

O Congresso representou, no caso brasileiro, a consagração de propostas que vinham sendo desenvolvidas aqui desde o início do século. Seu objetivo era tratar de todos os assuntos que direta ou indiretamente se referiam à criança, tanto no ponto de vista social, médico, pedagógico e higiênico, em geral, como particularmente em suas relações com a família, a sociedade e o Estado. (KUHLMANN JUNIOR., 1999, p. 90)

O evento consagrou as primeiras regulamentações sobre o atendimento de crianças pequenas em escolas maternais e jardins-de-infância.

Considerando a discussão até este momento, o atendimento a crianças de zero a seis anos no Brasil demonstra a diferença nas políticas e concepções latentes nos anos pré-1930 e, o início da participação direta do setor público para a infância, quando foram criados órgãos e projetos de assistência, saúde e educação após 1930. 


\section{A atenção à criança no Brasil de 1930 até 1990}

A crise cafeeira de 1929 inaugura a década de 1930 com modificações sociais, políticas e econômicas nacionais e internacionais determinantes para as ações de atendimento à infância brasileira. As iniciativas públicas, no início da década de 1930, derivaram dos conflitos de interesses da burguesia, dos trabalhadores e do Estado, levando o poder público a regulamentar o atendimento à infância.

De acordo com Kramer (1995), o período que se inicia na década de 1930 caracteriza-se pelo crescimento da participação do Estado na área da assistência à infância, por meio de lactários, jardins-de-infância, consultórios para mães, policlínicas infantis e escolas maternais. Afirma que o caráter do serviço oferecido era de cunho assistencialista, bem como se conservavam as tendências de atendimento médico e não se falava em educação das crianças de zero a seis anos.

Em 1930, foi criado o Ministério da Educação e Saúde Pública (Decreto n. 10.402, de 19 de novembro) que, por sua vez, criou, em 1940, o Departamento Nacional da Criança, órgão governamental que, convocando a sociedade para colaborar financeiramente, por quase 30 anos centralizou o atendimento à infância no Brasil sob uma política médica preventiva, distanciada da abordagem da origem dos problemas que eram sociais e econômicos latentes na divisão da sociedade em classes sociais tão desiguais.

Em 1932, foi publicado o "Manifesto dos Pioneiros da Educação Nova", intensamente influenciado pelos ideários religiosos, políticos e econômicos do contexto dessa década. O documento exigia, dentre outras questões, a criação de jardins de infância destinados à educação da população de zero a seis anos e defendia a escola pública. O texto do manifesto difundia uma visão mais integral da criança e vinculava educação, cultura e saúde.

O movimento escolanovista trouxe entusiasmo com a crença de que a educação mudaria o país “[...] encarando-a como panacéia para todos os males de uma sociedade profundamente marcada pelas desigualdades sociais", como aponta Kramer (1995, p. 131) e suscitou um novo pensamento educacional para a educação; contudo, outra vez, as inovações pedagógicas seriam somente para os jardins-de-infância, local frequentado 
pelos filhos da elite. Os parques infantis de Mário de Andrade, ambientes destinados às crianças das classes populares, continuaram com propostas de trabalhos educacionais diferenciados do que havia sido proposto pelos escolanovistas. Neste contexto, foram criados novos jardins de infância e proposto curso de formação de professores, para o atendimento das classes burguesas. No entanto, nas palavras de Oliveira (2005, p. 92).

A idéia de jardim-de-infância, todavia, gerou muitos debates entre políticos da época. Muitos criticavam por identificá-lo com as salas de asilo francesas, entendidos como locais de mera guarda das crianças. Outros defendiam por acreditarem que trariam vantagens para o desenvolvimento infantil, sob influência dos escolanovistas.

Em 1932, o trabalho feminino é regulamentado e as creches em empresas com mais de 30 funcionárias passam a ser de caráter obrigatório. Na década de 1990, a Constituição de 1988 passa a prever creches gratuitas para crianças de zero a seis anos, destinadas às mães trabalhadoras. O particular motivo da criação de creches para crianças pobres na década de 1940, de acordo com Oliveira (2005, p. 100), era o de evitar epidemias:

Entendidas como "mal necessário", as creches eram planejadas como instituição de saúde, com rotinas de triagem, lactário, pessoal auxiliar de enfermagem, preocupação com a higiene do ambiente físico. Por trás disso, buscava-se regular todos os atos da vida, particularmente dos membros das camadas populares.

Em 1940, os Parques Infantis do Departamento de Cultura da Prefeitura Municipal de São Paulo são regulamentados. Concebidos e geridos por Mário de Andrade, entre 1935-1938, fizeram parte do projeto de educação não escolar do governo municipal para as crianças de três a 12 anos das famílias operárias. A interpretação da concepção de criança e do Parque Infantil, segundo Kuhlmann Jr. (2000), sugeria que a criança fosse atendida num ambiente com elementos do folclore, da produção cultural e artística, das brincadeiras e dos jogos infantis com vistas à construção de uma identidade nacional. Esta iniciativa, na opinião de Faria (1995), representa a primeira experiência pública municipal de educação no Brasil para crianças de famílias operárias e a origem da rede de educação infantil paulistana. A autora lembra que neste projeto a criança teve sua 
infância valorizada por meio das características do ambiente integrado ao atendimento referido por Kuhlmann Jr. (2000), que já unia educação aos cuidados da criança.

Anos depois, na Consolidação das Leis de Ensino $n^{\circ} 17.698$, de 1947, vigora o primeiro decreto referindo-se à educação dos pequenos. A educação pré-escolar comparece como imperativo das famílias operárias e, por isso, os jardins de infância deveriam ser criados juntos às fábricas com a finalidade de ser uma oportunidade de a criança se desenvolver de forma harmônica num ambiente semelhante ao do lar. (KRAMER, 1995).

De 1930 até 1945, o país viveu o Estado Novo conhecido como a Era Vargas. Durante a Era Vargas, sobrevieram vários progressos na legislação trabalhista que culminaram na Consolidação das Leis Trabalhistas (CLT). Entre eles, um marco legal na legislação sobre as creches que previa a obrigatoriedade de as empresas particulares com mais de 30 funcionárias, acima de 16 anos, implantarem creches para os seus filhos, sem que, necessariamente, essa previsão fosse cumprida.

No decorrer da administração autoritária e populista de Vargas, houve uma expressiva influência nazifascista provinda da Europa que, no Brasil, culminou na busca de opções para o atendimento à infância pobre como forma de "aperfeiçoar a raça". Assim ocorreu com base na crença de que as condutas antissociais eram adquiridas hereditariamente e o meio social faria com que se instalassem ou não. Havia a crença de que caso a criança nascesse com uma herança genética para a criminalidade e se vivesse em um ambiente que beneficiasse a marginalidade, esta, consequentemente, seria um marginal.

Na esteira deste ponto de vista, em 1941, o Serviço de Assistência ao Menor (SAM) inaugura uma nova medida política. Na verdade, era um conjunto de normas e regras para instituições públicas e particulares que atendiam crianças, passando a assisti-las tanto judicial quanto administrativamente, como uma tentativa de eliminar uma possível convivência das crianças com a marginalidade. O objetivo inicial entre outros, era evitar a influência das famílias sobre as crianças, o que era efetivado através de ações como internações de menores em instituições particulares. Inicialmente, foi difundido que as instituições regidas pelo SAM eram a possibilidade exclusiva para uma boa educação à criança pobre. Sob tal alegação, a população carente economicamente recebia a 
orientação para que levassem seus filhos a essas instituições que, por sua vez, contraditoriamente, colaboraram com o aumento dos delinquentes, na medida em que a criança pobre não infratora convivia com menores infratores dentro das próprias instituições (KRAMER, 2003; RIZZINI, 1993).

Até os anos finais da década de 1930, as iniciativas assistenciais no Brasil permaneciam com caráter caritativo ou filantrópico, mas com o objetivo de proteger a ordem social. De 1930 a 1945, houve um progresso estatal no serviço social de amparo à infância pobre, com maior regulamentação em nível nacional da vida social da criança e do adolescente, com a organização da proteção à maternidade e à infância, com a manutenção do aparato legal justificada pela visão da infância como um problema social, além da regulamentação dos serviços de adoção. Nesse momento, percebem-se rupturas entre governo e a sociedade civil organizada, causadas pelas diferenças entre visão, procedimento e postura perante a infância. Os sanitaristas idealizaram um projeto de caráter filantrópico, a partir do ponto de vista de que o governo federal deveria ter controle de todas as instituições de assistência às crianças. A igreja católica, de sua parte, concebia a atenção à infância a partir de visão mais assistencialista, de natureza caritativa, religiosa, própria de ordens que se dedicavam às obras assistenciais, de maneira geral, e especificamente, à infância desamparada.

Em 1940 foi criado, pelo setor público, o Departamento Nacional da Criança, órgão vinculado ao Ministério da Educação e Saúde Pública, o qual concentrou o atendimento às crianças. Em 1941, criou-se o Serviço de Assistência a Menores, destinado aos menores delinquentes e abandonados.

Organismos internacionais assumem, neste tempo histórico, a definição das políticas assistenciais destinadas à infância nos países subdesenvolvidos, a exemplo do Fundo das Nações Unidas para a Criança (UNICEF), criado em 1946. O UNICEF inseria-se nas políticas assistenciais brasileiras agindo por meio de acordos com os vários domínios públicos. As deliberações internacionais desencadearam no Brasil um período de preocupações com a infância e, por conseguinte, o imperativo de constituir políticas educacionais ajustadas às crianças. Assim é que, na década de 40, se alargaram os empreendimentos governamentais para o atendimento às crianças, por meio de programas assistenciais, com ênfase no higienismo, na filantropia e na puericultura. 
[...] a UNESCO, através do UNICEF, começa a prestar assessoria aos especialistas de educação pré-escolar de diversos países. Recomenda-se então a busca de novas alternativas para atender aos menores de 7 anos, uma vez que os países subdesenvolvidos não dispõem dos recursos financeiros necessários para um atendimento à infância dentro dos padrões idealmente concebidos. (KRAMER, 1991, p. 37)

Além do UNICEF, outros organismos internacionais idealizaram e implantaram planos de ação comunitária para o terceiro mundo no intuito de combater a miséria (ROSEMBERG, 2002a), como o Fundo das Nações para a Alimentação (FAO), a Organização Mundial de Saúde (OMS) e a Organização Pan-americana de Saúde (OPS) (MONTENEGRO, 1999).

Para Rosemberg (2001), a crise financeira, em curso na época, compunha o panorama promissor para que o Estado empregasse políticas assistenciais como estratégia para seus interesses ditatoriais, além de manter o controle sobre a população sem, no entanto, perder a sua popularidade. Então, a Legião Brasileira de Assistência (LBA) surge em 1942, em meio a órgãos e iniciativas assistenciais no país como estratégia da política estatal voltadas à criança, com ênfase na educação. A LBA inicia o atendimento à criança de zero a seis anos e se torna referência no que diz respeito ao desenvolvimento de programas no campo da assistência social, sobretudo à maternidade e à infância, como uma ação compartilhada entre o poder público e privado, objetivando proteger a maternidade e a criança nos primeiros anos de vida. Funcionava sob o comando das Primeiras Damas da sociedade brasileira, o que Ihe imputava um caráter de filantropia, com ações fundamentalmente clientelistas que reproduziam a desigualdade da sociedade brasileira. Deste modo, a análise das políticas de educação e atendimento à criança pequena remete à LBA e seu principal programa na área: o Projeto Casulo, cujas unidades atendiam crianças durante quatro a oito horas diárias, realizando atividades de acordo com as especificidades de cada faixa etária, além de uma preocupação com a alimentação das crianças.

Kramer (2003) explica o surgimento da assistência pré-escolar, especificamente para crianças incluídas na faixa etária de zero a sete anos com a primeira iniciativa de educação infantil de massa no país proposta pela LBA, em 1942. Rosemberg (2003a) 
aponta alguns aspectos que podem ter contribuído para que este primeiro projeto de educação infantil de massa fosse implantando em larga escala: permitiu uma atuação direta do governo federal em vários municípios adotando a participação da comunidade como forma de custeio; reduziu o investimento federal; adotou um discurso preventivo no sentido de demonstrar que os cuidados dispensados aos pobres afastariam possíveis ameaças à integração nacional.

Deste modo, o atendimento pré-escolar no Brasil voltado para o aspecto educacional despontou sob dois contornos no contexto da primeira iniciativa de educação infantil de massa proposta pela LBA no país. Um deles, de caráter privado e de atuação reduzida, conduzido pela Organização Mundial de Educação Pré-Escolar (OMEP). A OMEP, fundada em 1948, almejava atender crianças de todas as classes sociais, de zero a sete anos, com destaque na psicologia da criança, dando atenção aos aspectos metodológicos e didáticos do processo educativo e da alfabetização. O outro, de caráter público federal, realizado pela Coordenação de Educação Pré-Escolar (COEPRE), sobre o qual discutiremos mais adiante.

Até metade da década de 1950, foram criadas poucas creches fora das indústrias. Todas filantrópicas, com seu foco no cuidado do corpo, entendimento arraigado por décadas nas instituições de educação infantil do país e que tem influenciado a representação da sociedade sobre a creche até hoje. Tempos depois, o governo destinou ajuda para estas instituições realizarem seus trabalhos, além de receberem auxílio financeiro das famílias ricas como forma de "caridade". Oliveira (2005) discute sobre o caráter assistencialista-protetoral destas creches, para observar que o atendimento se fundamentava na alimentação, cuidados da higiene e da segurança física. O trabalho orientado à educação e ao desenvolvimento intelectual e afetivo das crianças era pouco valorizado, reforçando a dicotomia entre cuidados e educação. Além do enfoque nos cuidados físicos, algumas instituições foram criadas como forma de evitar a marginalidade de crianças carentes e prevenir a criminalidade. Com este fim, em 1942, foi criada a "Casa da Criança”, pelo Departamento Nacional da Criança.

A partir da década de 1950, as creches em funcionamento fora das indústrias pretendiam suprir as carências da miséria por meio do trabalho de entidades filantrópicas, laicas e de caráter religioso. O atendimento se comprometia com os 
cuidados de higiene, alimentação e segurança física, sendo que o trabalho pedagógico para o desenvolvimento intelectual e afetivo das crianças continuava secundarizado.

As diferenças entre suas origens e seu desenvolvimento, do ponto de vista de Oliveira (1992, p. 21), esboçam a diferença entre creche e pré-escola nos anos 1950:

[...] crianças dos diferentes grupos sociais eram submetidas a contextos de desenvolvimento diferentes e desiguais nas famílias, nas creches e pré-escolas. Enquanto que as crianças pobres eram atendidas em creches com propostas que partiam de uma idéia de carência e deficiência, as crianças mais ricas eram colocadas em ambientes estimuladores e consideradas como tendo um processo dinâmico de viver e desenvolverse.

Em 1950, foi criado, em São Paulo, o Serviço de Educação Pré-Primária com a finalidade de oferecer assistência psicológica, pedagógica, atividades expressivas, recreativas e criativas, assim como, assistir as famílias no sentido de orientar a escolarização dos filhos, pois já havia preocupação com os índices de repetência na escola primária. As classes pré-escolares funcionavam precariamente junto a estabelecimentos escolares primários, sem recursos humanos e materiais adequados, e sem uma política educacional definida. Na mesma década, o Departamento Nacional da Criança foi transformado em Coordenação de Proteção Materno-Infantil, cujo principal objetivo era reduzir a mortalidade materna e infantil. Nos anos da década de 1960, esta Coordenação modifica-se em Divisão Nacional de Proteção Materno-Infantil.

Em 1953, foi fundado o Comitê Nacional Brasileiro da Organização Mundial para Educação Pré-Escolar (OMEP). Tratava-se de uma organização educativa internacional não governamental cuja finalidade era o atendimento às crianças de zero a sete anos de diferentes classes sociais. Os trabalhos da OMEP no Brasil conservavam uma postura filantrópica, porém demonstravam cuidado com o preparo das pessoas que trabalhariam com as crianças e com o enfoque metodológico do procedimento educativo, além de ser considerada a primeira instituição a defender políticas públicas voltadas à qualidade da Educação Infantil.

Até este momento, as políticas propostas no país e o atendimento à infância mantiveram a tutela da criança órfã e pobre pelo Estado, além da tutela de crianças 
infratoras e não infratoras na mesma instituição (SAM). A singularidade da atenção à infância no período ficou por conta da influência nazifascista e do tipo de cuidado prestado pelo Serviço de Assistência ao Menor (SAM). Comparece ainda alguma tendência em estabelecer atendimento educacional e políticas educacionais adequadas à criança, engendradas por organismos internacionais.

Os debates ocorridos no decorrer do $9^{\circ}$ Congresso Panamericano da Criança, realizado em Caracas, em 1948, ampliaram a importância dispensada aos direitos do "menor".

Em 1959, os direitos da criança e o cuidado social com a população infantil ilustraram as inquietações basilares no início do século XX, cujo marco foi a promulgação, em 1959, da Declaração Universal dos Direitos da Criança, pela Organização das Nações Unidas (ONU). A criança é, então, afirmada como um sujeito de direitos, atribuindo ao Estado e à Sociedade o dever de garantir esses direitos, quais sejam: direito à saúde, educação, profissionalização, lazer e segurança social.

Logo era o ano de 1964, e o governo da Ditadura Militar precisava tomar alguma atitude perante o conteúdo dessa Declaração, já que a infância passou a ser valorizada e a criança internacionalmente considerada como sujeito de direitos pela Organização das Nações Unidas (ONU). Sendo assim, o leitor poderá constatar que no ano de 1961, a aprovação da Lei de Diretrizes e Bases da Educação Nacional (Lei 4024/61) propôs a inclusão dos jardins de infância no sistema de ensino por meio dos seus artigos 23 e 24, porém, a generalidade da Lei não permitiu que ações efetivas fossem realizadas, apesar do aumento da demanda por creches e pré-escolas. Observe ainda que a educação infantil será novamente mencionada na Lei 5692, aprovada em 1971, retrocedendo ao que já se lia no artigo 24, da Lei 4024. A nova menção no parágrafo $2^{\circ}$, do art. 19 , assegura que "os sistemas valerão para as crianças de idade inferior a 7 anos que recebam conveniente educação em escolas maternais, jardins-de-infância ou instituições equivalentes" (LDB $5692 / 71)$.

Cabe lembrar que em abril de 1964, iniciou-se a ditadura militar no Brasil (19641985) após um golpe das forças armadas ao governo de João Goulart. Um dos principais motivos para o golpe foi o receio da implantação de reformas, especialmente a reforma agrária, que traria como consequência direta a divisão das grandes propriedades de terra, 
reivindicada por políticos e intelectuais desde a abolição (1888), levando a diminuição do poder dos "coronéis" (proprietários de terras no Nordeste) que mantinham os trabalhadores do campo sob seus domínios, inclusive manipulando-os nas campanhas eleitorais.

O Governo adotou o modelo desenvolvimentista para recuperar o crescimento econômico com o fortalecimento do empresariado industrial por acreditar ser este segmento capaz de favorecer o progresso almejado. Esse objetivo governamental acelerou a demanda por educação que, por sua vez, abonou os acordos do MEC com a Agency for International Development (AID), conhecidos como "Acordos MEC-Usaid". O texto do acordo MEC-Usaid sobre o desenvolvimento do atendimento à primeira infância era genérico e com significados duplos, como na já comentada LDB de 1961. Mais uma vez, o Estado mostrou sua desconsideração para com a criança.

A rede particular de educação para a criança pequena, segundo Rosemberg (1999), se espalhou e o atendimento das crianças pobres na rede pública ocorria por meio de programas de massa, com o baixo custo e de educação compensatória. A UNESCO e o UNICEF divulgaram este modelo como alternativa para países do Terceiro Mundo, sem condições de financiar, simultaneamente, os ensinos de $1^{\circ}$ e $2^{\circ}$ graus e a educação préescolar. De acordo com Rosemberg (2002), entre os anos de 1960 e 1965, a UNESCO, além de operar como formadora de opiniões, foi responsável por $1 \%$ dos investimentos educacionais, o UNICEF por $1,6 \%$ e a Usaid $73 \%$, o que realça a atuação dos organismos internacionais no Brasil.

Os modelos de Educação Infantil de baixo custo, no entendimento de Kramer (1995, p. 11), foram concebidos “[...] como solução para os problemas tanto educacionais como sociais que a sociedade brasileira enfrenta." Os programas de atendimento à infância que precederam a década de 1960 foram de caráter assistencialista, uma educação destinada às crianças carentes para assistir suas necessidades físicas e biológicas e adentram pela década de 1970, propondo atendimento em creches para crianças menores. Ao mesmo tempo, as políticas educacionais se voltam para a pré-escola com programas educacionais compensatórios e de assistência à educação de crianças de zero a seis anos. Neste período, as políticas governamentais incentivavam programas 
emergenciais para entidades filantrópicas, assistenciais ou de iniciativas comunitárias, nos quais mães cuidavam de turmas com mais de cem crianças na pré-escola.

No final da década de 1960, devido a mudanças no modelo econômico brasileiro e suas consequentes exigências, os governos voltaram sua atenção para a educação das classes populares com objetivo de qualificar a força de trabalho para maior produtividade, a fim de solidificar o modelo de internacionalização do mercado interno.

Nos anos de 1960 e 1970, incide uma proliferação da assistência social sob a influência da teoria da "privação cultural" difundida nos Estados Unidos que, por sua vez, passa a influenciar as políticas desenvolvidas nas instituições de atendimento à criança pequena brasileira, de modo que tais instituições passam a ser vistas como resposta para compensar as carências das crianças e principalmente prevenir o fracasso escolar (KRAMER, 1995). Neste período, a LBA oferecia subsídios financeiros e ajuda técnica às instituições de atendimento à criança, com objetivo de influenciar suas diretrizes, além de incentivar o atendimento como ascensão social à criança carente. Diante desta nova perspectiva, os indicadores de pobreza, e não mais a condição da mãe trabalhadora, passaram a ser o critério de seletividade e inclusão aos programas de creche ou préescola no país.

A partir da década de 1970, a importância da educação infantil passa a ser reconhecida pelo Estado no plano ideológico, uma vez que a legislação não havia determinado sobre o direito da criança e dever do Estado. No entanto, as políticas governamentais começam a ampliar o atendimento, em especial às crianças de quatro a seis anos, unicamente por causa da crescente evasão escolar e da repetência das crianças das classes pobres no ensino primário. Perante esta conjuntura, a educação pré-escolar é apontada como solução das carências culturais destas crianças para que consigam sucesso no ensino escolar. Constitui-se, então, no Brasil, uma política de atendimento à infância pautada na preparação, na educação compensatória para a inserção da criança no ensino escolar; um modelo de atendimento em massa, com menor custo possível, a fim de atender um maior número de crianças das camadas populares, o que denota a presença dos interesses neoliberais dos organismos internacionais.

No período de transição dos anos 60 para os primeiros anos da década de 70 do século XX, a evasão, a reprovação e a repetência evidenciaram o fracasso da escola 
primária, apesar das tentativas de superação. Este foi o contexto causador das discussões da necessidade da educação pré-escolar em um período em que se viu a inovação de políticas sociais nas áreas de educação, saúde, assistência social, previdência, etc. O lema da era militar - 1964 a 1985 - era a segurança e o desenvolvimento do país. Ambos seriam alcançados conforme as desigualdades e conflitos se enfraquecessem. Portanto, o Projeto Casulo, dentre outros, eram estratégias preventivas junto ao segmento social empobrecido para diminuir as diferenças e desigualdades e, com isso, diminuir as possibilidades de conflitos. Rosemberg (2003) confirma essa finalidade de assistir à infância e prevenir a luta de classes. Após vinte anos de atuação da LBA no país como órgão de assistência social com extenso empreendimento na infância brasileira, a mudança do regime político do país provoca uma crise financeira, uma vez que o governo da ditadura militar reduz seus recursos. Com o decreto assinado pelo Presidente da República implantando a Loteria Esportiva Federal, a LBA passou a receber parte da renda líquida deste jogo (KRAMER, 1995). As ações de apoio à creche e pré-escola continuaram sendo realizadas, destacadamente o Projeto Casulo, com início em meados de 1976, em meio ao dualismo entre o preceito assistencialista e o educacional na préescola e em prol da liberação das mães para o mercado de trabalho. Este projeto foi uma consequência da aliança entre o governo e organismos internacionais, principalmente o UNICEF, o qual pretendia a implantação de programas para as crianças pobres desde o decorrer da década de 1960.

O Projeto Casulo oferecia atendimento de cuidados higiênicos, nutricionais, médico e odontológico para crianças de até seis anos de idade. Tinha o objetivo de cuidar das crianças de zero a seis anos por um período de quatro a oito horas diárias, para que as mães pudessem trabalhar. Tais estabelecimentos proporcionavam, além da assistência à saúde, atividades de preparação para as séries iniciais do $1^{\circ}$ grau, o que deixa clara a intenção governamental de promover uma educação de caráter compensatório, que, indiretamente, culpabilizaria a criança por seu fracasso, uma vez que era considerada carente culturalmente. A pré-escola passa a ter a tarefa de solucionar esse problema para evitar a reprovação e a evasão nas séries do $1^{\circ}$ grau.

Quanto ao atendimento prestado às crianças inseridas no Projeto Casulo, o mesmo estava pautado na guarda, cuidado e apoio nutricional e constituía-se em uma 
política pobre, para pobres, de cunho clientelista, excludente e fragmentado (ROSEMBERG, 2001). No entanto, não há como negar a importância da LBA e de seu Projeto Casulo para a política de educação infantil e, principalmente, para o avanço constitucional alcançado no final da década de 1980, quando esta passa a se constituir como um direito da criança. Isto porque foi através da expansão do atendimento propiciado pelo projeto que a sociedade pôde reconhecer a importância deste tipo de atendimento, dando, ao mesmo tempo, subsídios para que os profissionais da área da educação passassem a refletir sobre o modelo de educação compensatória proposto. Como já dito, a promulgação da Constituição Federal de 1988 e instrumentos legais posteriores, a Educação Infantil passou a ser responsabilidade do Estado, inserida na primeira etapa da educação básica. Tal determinação acarretou a transferência da política de Educação Infantil da área da assistência social para a área da educação. Esta alteração, ao mesmo tempo em que proporcionou um avanço, visto que o direito à Educação Infantil passa a ser de toda a criança, independente de sua condição econômica e social, acarretou também o afastamento da assistência social deste tipo de atendimento, uma vez que gestores e movimentos sociais envolvidos incentivaram estratégias para que a política de Educação Infantil fosse, de fato, assumida como direito universal e responsabilidade governamental nos termos da LDBEN/96.

O SAM, por seu lado, fracassou e foi extinto em 1964, por não cumprir o papel de proteção à criança. Com o mesmo propósito foi criada, nesse ano, a Fundação Nacional do Bem-Estar do Menor (FUNABEM), efetivando a transição entre os Códigos de 1927 e 1979 (Lei 6.667, de 10 de outubro de 1979), que dispôs sobre a proteção do "menor em situação irregular”. De caráter normativo e supervisor, a FUNABEM tinha como objetivo a formulação e implantação de uma política nacional do bem-estar do menor, passando a supervisionar todas as entidades públicas e privadas que prestavam atendimento à criança e ao adolescente. A execução dessas políticas ficava a cargo das Fundações Estaduais do Bem-Estar do Menor (FEBEM). Como exemplo das ações de caráter filantrópico, os médicos vinculados eram responsáveis por intervenções extra-asilares, voltadas para as famílias pobres no sentido de prevenir o abandono de crianças, a educação inadequada e a delinquência. 
Em relação à infância, durante o período da ditadura militar, o atendimento à criança permaneceu da mesma forma, assistencialista e preconceituoso. O Estado considerava o menor como "objeto de segurança nacional”. Até a década de 70 a atenção à infância se dividia em dois setores: o das crianças pequenas que eram vinculadas aos sistemas educacionais, e o dos bebês, cuja educação cabia aos órgãos da saúde e de assistência. Ao chegar à década de 70, a demanda da pré-escola já havia aumentado expressivamente, o que exigiu medidas para o processo de municipalização da educação pré-escolar pública.

No final dessa década e, principalmente na década de 80, surgiu em São Paulo o “Movimento de Luta por Creches". Este acontecimento fortaleceu a influência sobre o poder público, de tal modo que houve aumento do número de creches e pré-escolas mantidas por ele e a multiplicação de creches e pré-escolas particulares conveniadas com os governos municipais, estaduais e federal. Oliveira (2005, p. 112) descreve o cenário que envolvia a luta por creches:

Mesmo assim, a insuficiência do número de crianças atendidas nas creches pressionava o poder público a incentivar outras iniciativas de atendimento à criança pequena. Eram as 'mães crecheiras', os 'lares vicinais', 'creches domiciliares' ou 'creches lares', programas assistencialistas de baixo custo estruturados com a utilização de recursos comunitários, tal como ocorria em muitos países do chamado Terceiro Mundo.

No período entre 1974-1975, o pré-escolar recebeu destaque no plano oficial e passou a ser considerado como importante no sistema educacional. O MEC divulgou diversos pareceres e documentos, entre eles o parecer do Conselho Federal de Educação 2018/74 que fundamentou, recomendou e reafirmou a prioridade da pré-escola no atendimento das crianças oriundas das famílias de baixa renda, visando, com isso, equalizar as oportunidades de acesso e permanência, além de oferecer formação escolar que compensasse a marginalização e carência cultural a que estas crianças estavam submetidas em seu meio. As crianças provenientes dos meios de baixo nível socioeconômico eram consideradas portadoras de um déficit cultural devido à falta de condições de seu meio sociocultural considerado carente em relação aos padrões culturais convencionados como adequados pelas classes sociais de nível elevado. 0 
referido parecer eleva a educação pré-escolar a uma posição de destaque no sistema educacional, ao mesmo tempo em que lhe confere um caráter compensatório. Isto significa promover a educação pré-escolar como redentora de todos os problemas da escola de $1^{\circ}$ grau da época, suprindo a suposta carência cultural das crianças das classes sociais menos favorecidas, incapazes de bom desempenho nessa faixa de ensino. Sua função passava a ser o atendimento aos mais carentes e a uniformização de oportunidades, ou seja, preparatória pra o $1^{\circ}$ grau. Entretanto, o atendimento à maioria das crianças em idade pré-escolar continuava distante de ser concretizado.

Como se vê, o conceito de educação compensatória ${ }^{7}$ influenciou as propostas de trabalhos elaborados nas creches e pré-escolas que atendiam as crianças das classes menos favorecidas. Essas propostas iam desde a estimulação precoce ao trabalho com a alfabetização, tendo como suporte a educação tecnicista desenvolvida na época, a qual acaba influenciando os trabalhos educativos proporcionados nos parques infantis e escolas maternais. Essa educação era considerada uma “educação sistematizada”, uma educação que prepararia para o ensino fundamental.

O Ministério da Educação e Cultura - MEC cria, em 1975, outro tipo de atendimento pré-escolar no Brasil, desta vez de caráter público federal que foi efetivado pela Coordenação de Educação Pré-Escolar (COEPRE). Em consequência, os documentos oficiais indicam que a educação pré-escolar deve utilizar métodos de baixo custo e atender a um extenso número de crianças com o papel e a função de redimir todos os problemas sociais. $\mathrm{O}$ atendimento às crianças se constitui para mascarar as contradições

\footnotetext{
${ }^{7} \mathrm{O}$ conceito de educação compensatória como antídoto à privação cultural teve origem no pensamento de Pestalozzi, Froebel, Montessori e McMillan. Esses estudiosos postulavam que a criança "[...] precisa ser recuperada ou construída ou, ainda, reconstruída para a sociedade através de processos pedagógicos" (REDIN, 1988, p. 27). De acordo com esta concepção de criança, os pesquisadores citados desenvolveram seus trabalhos na Europa com crianças dos meios menos favorecidos, gerando a ideia de pré-escola "[...] como uma forma de suprir a miséria, a pobreza, a negligência das famílias" (KRAMER, 1995, p. 26). O conceito da educação compensatória baseia-se na abordagem da privação cultural que, por sua vez, apóiase na concepção de que as crianças das classes populares apresentam carência ou desvantagens de ordem social, sob a forma de perturbações intelectuais, linguísticas e afetivas. Através de métodos pedagógicos adequados e da intervenção precoce, pretende-se reduzir ou eliminar, ou seja, compensar as deficiências do desempenho destas crianças nas situações escolares de aprendizagem. O padrão de comparação do desempenho é aquele da criança da classe média. A educação compensatória deveria garantir as mesmas oportunidades de sucesso escolar e ascensão social às crianças das classes populares, desconsiderando que a igualdade de oportunidades supõe uma concreta igualdade de condições. A educação pré-escolar, assim vista, produz desigualdades e se propõe uma tarefa que extrapola suas possibilidades de resolver problemas de desigualdades escolares e sociais.
} 
sociais que separam as crianças conforme sua condição econômica: as creches passam a existir para "abrigar" crianças pobres, de até seis anos; enquanto os jardins de infância surgem para acolher crianças ricas, acima de três anos, assegurando seu desenvolvimento e sua educação.

Rosenberg (2002) assevera que a adoção de modelos de larga escala para a Educação Infantil com baixo investimento público trouxe, juntamente com o aumento rápido do atendimento às crianças, o número crescente de professores sem formação adequada e a retenção de crianças em idade escolar na pré-escola. Estas medidas, segundo a autora, deram procedência a novos processos de exclusão social e a um atraso no processo "de construção nacional de um modelo de educação infantil democrático, de qualidade, centrado na criança" (ROSENBERG, 2002, p. 39). Inversamente, Rossetti-Ferreira, Ramon e Silva (2002, p. 90) argumentam sobre o tipo de política educacional que atenderia aos diretos da criança:

[...] As principais políticas para a educação e cuidado infantil não podem, porém ser reduzidas a uma ajuda aos que necessitam, a uma educação para a submissão e exclusão, pois essas políticas podem colaborar para a construção de uma cidadania assistida e tutelada. Elas devem ter como objetivo a promoção da autonomia e o exercício da cidadania, para que esta seja responsável e competente. Uma educação de qualidade como um direito é o instrumento básico para alcançar esses objetivos. A educação e o cuidado infantil devem ser propostos como meio de inclusão social, oferecendo condições que permitam a construção de uma cidadania emancipada.

A partir de 1979, o UNICEF passou a incentivar as creches comunitárias, cuja expansão deu-se na década de 1980, com os movimentos sociais (associações de moradores, grupos de luta contra a carestia, etc.); assumidas pelas secretarias municipais de educação em 2002.

No ano de 1979, o Movimento de Luta por Creches foi oficializado no âmbito do I Congresso da Mulher Paulista. O reconhecimento do caráter educativo somado à necessidade da mulher trabalhar levou a classe média a reclamar por creches, que neste período agregam a dimensão assistencial à educacional. 
No início da década de 1980, a educação pré-escolar foi instituída oficialmente, percebida como política governamental através do III Plano Setorial de Educação, Cultura e Desporto. Neste período, apareceram dúvidas sobre o papel compensatório da préescola e uma nova identidade para as creches despontava, em atenção ao direito da criança e da mãe a um atendimento público respeitoso.

A educação pré-escolar brasileira inicia na década de 1980 em meio a fortes críticas à teoria da privação cultural e à ideia da pré-escola compensatória. Em dezembro de 1981, o MEC-COEPRE ${ }^{8}$ publicou o "Programa Nacional de Educação Pré-Escolar" (BRASIL. MINISTÉRIO DA EDUCAÇÃO E CULTURA. SECRETARIA GERAL. COMISSÃO DE COORDENAÇÃO GERAL, 1981) que estabeleceu diretrizes, prioridades, metas, estratégia e plano de ação da política do pré-escolar e foi desenvolvido pelo MEC-COEPRE, pelas Secretarias de Educação e pelo Mobral em um período em que a educação das crianças até seis anos de idade não era referida na Constituição em vigor. O programa fundamenta-se na importância dos primeiros anos de vida para o desenvolvimento do ser humano, nas precárias condições de vida de grande parte da população infantil brasileira da época e na possibilidade de diminuir os seus efeitos danosos para o desenvolvimento futuro da criança. Recomenda o funcionamento em espaços físicos disponíveis, a participação da comunidade e destaca a alimentação e as ações de saúde como imprescindíveis, e as atividades físicas e artísticas, como basilares para o desenvolvimento da individualidade infantil.

A educação pré-escolar passa então ser encarada como tendo “objetivos em si mesmos", porém, nas entrelinhas do documento, constata-se a ideia da pré-escola capaz de corrigir as falhas do sistema educacional. O documento deixa de proclamar a função compensatória da pré-escola, que já não prepararia para a escolaridade posterior, mas seria capaz de superar males sociais e, consequentemente, resolver problemas educacionais. Essa ideia serviu para justificar propostas sem critérios mínimos de qualidade, visto que perdera sua função e agora era importante por si e em si mesma. Entretanto, é reconhecido o seu valor para a educação pré-escolar por ser a primeira proposta delineada para as crianças da faixa etária de quatro a seis anos, em nível

\footnotetext{
${ }^{8}$ COEPRE - Coordenação de Educação Pré-Escolar, órgão oficial responsável por dinamizar e centralizar as atividades desenvolvidas pelas Secretarias Estaduais e Municipais de Educação neste período.
} 
nacional, e por inserir esse nível de educação no debate das decisões políticoadministrativas, avançando para além das questões pedagógicas.

Em 1981, o Programa Nacional de Educação Pré-Escolar - MEC/COEPRE inicia suas atividades utilizando como estratégias de execução o estabelecimento de acordos entre as Secretarias Estaduais de Educação para agenciar uma pré-escola de baixo custo, aproveitando espaços ociosos das comunidades e a mão de obra de mães voluntárias; a outra estratégia do programa, ainda em 1981, foi a integração do MOBRAL (extinto em 1985) com a responsabilidade de 50\% do atendimento pré-escolar da rede pública a fim de propagar ações de atendimento em massa para a criança (KRAMER, 1995). Isso se deu sob a intensa influência da teoria da privação cultural que, na época, confiava na educação pré-escolar como solução para a reprovação e evasão escolar. Após a sua extinção, ocorre a passagem de seu programa de atendimento à infância para a Secretaria de Educação Básica, a qual coordenou os programas municipais de educação pré-escolar através de convênios entre as Delegacias do MEC e as Prefeituras. Em 1987, o COEPRE é extinto e seu programa Pré-escolar passa a ser coordenado pela Secretaria de Ensino Básico do MEC, inserido no setor de ensino do $1^{\circ}$ grau e supletivo.

$\mathrm{Na}$ década de 1980, ocorreu a expansão das matrículas, consolidando sua importância como a primeira fase do processo escolar. Surgem currículos e propostas pedagógicas tanto nas Secretarias de Educação, como nas pré-escolas. No III Plano Setorial de Educação, Cultura e Desporto (PSECD) de 1980-1985, a educação pré-escolar recebeu tratamento político, identificando-a como componente importante da política social. Prevaleceram as ideias de que a educação pré-escolar resolveria os problemas decorrentes das privações provocadas pelo meio social em que as crianças viviam e que causavam problemas ao seu desenvolvimento e aprendizagem.

Até a década de 1980, as iniciativas particulares e as políticas públicas dirigidas às crianças menores de sete anos no Brasil foram assistencialistas e compensatórias. No decorrer dessa década, a educação pré-escolar enfrentou dificuldades alusivas à ausência de uma política global e integrada, mas por outro lado, a consciência social da Educação Infantil como um direito das crianças pequenas à educação e um direito de assistência aos filhos de pais e mães trabalhadores desponta. A falta de coordenação entre programas educacionais e de saúde, a predominância do ponto de vista preparatório para o $1^{\circ}$ grau, a 
carência de professor qualificado, a escassez de programas inovadores e a falta da participação familiar e da sociedade foram algumas dessas dificuldades. Rosemberg (2002) observa que nos países subdesenvolvidos, os organismos internacionais têm influenciado profundamente as políticas para a educação infantil, com mínimo investimento público por meio de modelos "não formais". A UNESCO e o UNICEF desempenharam seu papel a partir dos anos 1970. Contudo, a maior influência deriva do Banco Mundial (BM) a partir dos anos de 1990. A autora argumenta que nesses países a Educação Infantil incorporou como particularidade o espaço físico inadequado, a precariedade de material pedagógico e a ausência de qualificação profissional. Os resultados das políticas neoliberais para a área da educação infantil são os baixos investimentos e falta de uma política séria de formação dos profissionais.

O caminho percorrido pelo atendimento à infância no Brasil, até chegar à Educação Infantil, passou também pela luta dos movimentos por creches mobilizadas por mães trabalhadoras e mães de classe média, vinculadas ao processo de redemocratização do país, sendo que durante as décadas de 1970 e 1980, a ação era na direção do imperativo de se tornar direito a Educação Infantil. O final da década de 1980 foi demarcado pela ação dos movimentos sociais em prol da Constituinte, dentre eles, o Movimento Criança Pró-constituinte e o Movimento de Mulheres/Feminista.

A combinação destes fatores às questões sociais, políticas e econômicas do período, ensejou um movimento da sociedade civil e de órgãos governamentais para que o atendimento às crianças de zero a seis anos fosse amplamente reconhecido na Constituição de 1988, culminando no reconhecimento da Educação Infantil como um direito da criança, e não mais da mãe ou do pai trabalhadores.

Em 1988, a Constituição Federal define o atendimento institucionalizado às crianças como direito social, conforme dispõe artigo 208, inciso IV: “O dever do Estado com a educação será efetivado mediante a garantia de [...] atendimento em creche e préescola às crianças de zero a seis anos de idade" (BRASIL, 1988). O artigo 227 dispõe sobre os direitos da infância brasileira de forma abrangente: 
É dever da família, da sociedade e do Estado assegurar à criança e ao adolescente, com absoluta prioridade, o direito à vida, à saúde, à alimentação, à educação, ao lazer, à profissionalização, à cultura, à dignidade, ao respeito, à liberdade e a sobrevivência familiar comunitária. (BRASIL, 1988)

Inaugura-se no Brasil um extenso e tortuoso processo de transformação do caráter assistencial para o educacional o atendimento das crianças das creches e préescolas, a educação de zero a seis anos de idade como direito da criança e não da mãe trabalhadora. A recomendação legal de uma função educativa ao atendimento institucionalizado da criança desencadeou discussões sobre o tipo de trabalho pedagógico adequado a esse segmento; sua normatização; a revisão do papel dos professores junto à necessidade de formação específica, além das diretrizes curriculares a serem seguidas. A creche é legalizada como extensão do direito universal à educação das crianças de zero a seis anos, integrada à Educação Infantil e complementar à educação familiar, o que passou a impulsionar as lutas, a exemplo do Movimento Interfóruns de Educação infantil no Brasil (MIEIB) pela construção da sua identidade institucional ligada às instituições eminentemente educativas, ou seja, "[...] a creche organiza-se para apoiar o desenvolvimento, promover a aprendizagem, mediar o processo de construção de conhecimentos e habilidades, por parte da criança, procurando ajudá-la a ir mais longe possível nesse processo" (DIDONET, 2001, p. 15). Contudo, esse caminho tem sido de avanços e retrocessos a antigas políticas e concepções já experimentadas na história da atenção à criança e da infância brasileira referidas por nós.

Certamente, a Carta Magna de 1988 trouxe um avanço na concepção de criança ao reconhecê-la como sujeito de direitos, portanto cidadã. No entanto, foi omissa por não ter disposto sobre a obrigação de oferta de Educação Infantil pelo Estado, como o fez com o ensino fundamental. Cinco anos após a aprovação da Constituição Federal de 1988, O MEC criou um novo projeto, a Coordenação de Educação Infantil (COEDI), com o propósito de favorecer a ampliação da educação infantil com qualidade. Em 1993, foi elaborado o documento "Políticas para a Educação Infantil”, com a finalidade de colocar essas ideias em prática. Entretanto, tais propostas foram interrompidas durante o mandato de Fernando Henrique Cardoso (ROSEMBERG, 2002). 


\section{A atenção à criança no Brasil de 1990 aos dias atuais...}

As influências do Banco Mundial e das organizações internacionais se fizeram presentes no panorama das políticas educacionais na América-latina e, sobretudo no Brasil, a partir da década de 1990. Nomeadamente na área da Educação Infantil, o BM delineia uma nova concepção de "desenvolvimento infantil”, que orientou programas dedicados ao combate à pobreza, usando para isso modelos assistencialistas fracassados da década de 1970, como as creches filantrópicas e domiciliares (ROSEMBERG, 2002a). Conforme informa Rosemberg (2002, p. 8), “[...] quando o BM entra em cena no campo da Educação Infantil nos 90, recupera propostas equivalentes às da Unesco e do Unicef dos anos 70, desconsiderando o pequeno percurso brasileiro na construção de uma Educação Infantil democrática."

A crítica da autora tem relação com o discurso do BM sobre a ênfase na consideração que investir no desenvolvimento da criança pequena significa investimento no futuro. Para Rossetti-Ferreira, Ramon e Silva (2002), este é um discurso retrógado porque é referenciado nas ideias já superadas das neurociências, as quais relacionam a primeira infância a um período do desenvolvimento humano ótimo para que se oportunizem experiências ricas às crianças, especialmente, às populações muito pobres.

Neste contexto, as pressões oriundas de organizações não governamentais incorporando a ação de um "movimento social" em direção a uma proteção integral à infância (Pastoral do Menor, setores da sociedade civil, entre outras) promovem o surgimento de uma legislação para a infância em que os direitos das crianças e dos adolescentes são legalmente detalhados: o Estatuto da Criança e do Adolescente (ECA) em 1990, pela Lei Federal 8.069 (BRASIL, 1990). A esta altura, a FUNABEM é extinta e são focalizados os direitos da criança e do adolescente, na medida em que passam a ser vistos como sujeitos de direitos. Hoje é o ECA que norteia todas as instituições que trabalham com crianças, infratoras ou não.

Em 1993, com a promulgação da Lei Orgânica da Assistência Social - LOAS, $n^{\circ}$ 8.742, são regulamentados e estabelecidos normas e critérios para a organização da assistência social em prol da infância, para o amparo às crianças e adolescentes carentes, 
entre outros procedimentos. Com a implementação dessas e outras leis, o Estado assume encargos sobre a assistência de crianças e adolescentes.

No período compreendido entre 1980 e 1990, a pré-escola brasileira recebeu reconhecimento político e social e passou a ser encarada pela sociedade como necessária devido ao aumento da urbanização e a alteração da estrutura e dos papéis no interior da família. Na área da política educacional, foi proclamada oficialmente a importância da educação pré-escolar. Em 1986, o Presidente da República José Sarney, anunciou pessoalmente a expressão "primeiro a criança", como slogan do "Programa Primeiro a Criança", baseado neste princípio, além de estabelecer que as creches e pré-escolas fariam parte dos sistemas educacionais. As ações relativas ao atendimento pré-escolar foram incentivadas pelo MEC através da aplicação de recursos financeiros, da definição de objetivos, de diretrizes gerais e da proposição de elaboração de programas municipais e estaduais de educação pré-escolar (Programa Nacional de Educação Pré-Escolar; Programa de Educação Pré-Escolar do MOBRAL; o PROAPE - Programa de Atendimento ao Pré-Escolar e o PROEPRE - Programa de Capacitação de Professores de Educação PréEscolar, baseado na teoria construtivista de Jean Piaget).

Até este momento, o exame dos acontecimentos demonstra que a educação préescolar trilhou sua história como nasceu, com fins assistencialistas, caracterizados como pretensamente educacionais, pois mesmo quando proclamou uma função educativa, visava à compensação.

Na década de 1990 do século XX, o Estado brasileiro privatizou empresas estatais para resolver seu problema de déficit público no lugar de um projeto de ampliação industrial. O reflexo na educação pode ser observado com o aumento da criação de programas dirigidos às classes populares que mantinham um caráter compensatório. Essa década constituiu um marco histórico para a área da educação infantil. A Constituição Federal de 1988 definiu a creche e a pré-escola como direitos da criança à educação; o Estatuto da Criança e do Adolescente, em paralelo à Convenção dos Direitos da Criança, em 1990, legitimava a criança como sujeito de direitos; a Lei de Diretrizes e Bases da Educação Nacional, de 1996, incluía a educação infantil, organizada em creche e préescola, como a primeira etapa da educação básica. Estudos sobre a infância e experiências pedagógicas com crianças, em nível internacional e nacional, expandiam as 
perspectivas de atendimento segundo a especificidade da educação infantil. Neste período, Redin (1988) já discutia sobre como a concepção de pré-escola vigente acarretava entraves à proposição de objetivos e função próprios:

[...] a representação da criança no atendimento pré-escolar, no Brasil, tem algumas constantes: a criança como possível fracassada; a criança carente e incapaz; a criança marginalizada e a igualdade de oportunidades; a criança estorvo para o desenvolvimento do processo de urbanização e internacionalização do capitalismo dependente brasileiro; a criança carente e deficiente, objeto de assistência à saúde, higiene, recreação, alimentação etc.

Estas representações de criança que se manifestam nas práticas de educação pré-escolar no Brasil mostram um descompromisso da cultura oficial dominante com a história da própria criança. Ela é vista a partir do padrão adulto burguês, capitalista, produtivo, idealista, paternalista e assistencialista. (REDIN, 1988, p. 30)

Prosseguindo, em 1994, o MEC guiado pela Constituição Federal e pelo Estatuto da Criança e do Adolescente, formulou a Política Nacional de Educação Infantil, em que são propostas as diretrizes gerais para uma Política de Educação Infantil e as ações que o ministério coordenaria nos anos seguintes com relação à educação de crianças de zero aos seis anos de idade. Nas diretrizes gerais, a proposta traz como princípios para a Educação Infantil o objetivo de complementar a ação familiar, proporcionar condições adequadas de desenvolvimento físico, emocional, cognitivo e social para a criança, ampliar suas experiências e conhecimentos, estimulando seu interesse pelo processo de transformação da natureza e pela convivência em sociedade.

As ações educativas da creche e da pré-escola deveriam ser completadas pelas de saúde e de assistência, realizadas de forma articulada com os setores competentes. $O$ currículo deveria trazer em sua concepção e administração, a consideração do grau de desenvolvimento da criança, a diversidade social e cultural das populações infantis e o conhecimento que se pretendia universalizar. Pedagogicamente, as diretrizes concebiam a criança como um ser completo, ativo, capaz, motivado pela necessidade de ampliar seus conhecimentos e experiências e de alcançar autonomia progressiva frente às condições de seu meio. A criança comparece no documento como sujeito social e histórico, pertencente a uma família que está inserida numa sociedade, numa 
determinada cultura, num determinado momento histórico, sendo marcada pelo seu meio social e marcando-o.

As diretrizes concebem ainda que o desenvolvimento psicológico acontece a partir das interações estabelecidas entre a criança e o seu meio físico e social. A interação exerceria papel preponderante no desenvolvimento infantil e na construção do conhecimento, tornando-se efetiva quando ocorresse de forma lúdica e afetiva. 0 documento propõe duas funções complementares à educação infantil: cuidar e educar segundo os princípios acima. A contribuição deste documento é representada pela propositura de que este nível tenha objetivos próprios, tanto em termos de desenvolvimento como de conhecimento; dimensiona o jogo, a atividade cooperativa, a interação social e interpessoal, o papel do adulto, a importância da criança vivenciar plenamente este período, a consideração da diversidade cultural a que a criança deve ter acesso e a criança como sujeito que age organizando informações para construir seus conhecimentos.

Outra contribuição diz respeito à definição do papel do educador como um organizador do ambiente, como o planejador das experiências de aprendizagem, o mediador que propõe atividades, lança desafios, avalia as crianças. Redin (1988) elucida o que seria função pedagógica da pré-escola:

Quando dizemos que a pré-escola tem uma função pedagógica, estamos nos referindo, portanto, a um trabalho que toma a realidade e os conhecimentos infantis como ponto de partida e os amplia, através de atividades que têm um significado concreto, para a vida das crianças e que, simultaneamente, asseguram a aquisição de novos conhecimentos. (REDIN, 1988, p. 38)

A publicação da Constituição de 1988 (BRASIL, 1988) determina a urgência no estabelecimento de políticas sociais e prioridades orçamentárias, de elaboração de legislação complementar e da ampliação do atendimento em creches e pré-escolas.

A promulgação da lei $n^{\circ}$ 9.394, de Diretrizes e Bases da Educação Nacional (LDBEN/96) (BRASIL. MINISTÉRIO DA EDUCAÇÃO E CULTURA, 1996), bem como as resoluções educacionais em benefício da infância dela decorrentes, demarcam um avanço 
no atendimento às crianças. Nos textos dos documentos oficiais, a Educação Infantil passa a ser legalmente concebida e reconhecida como a etapa inicial da educação básica; a criança é conceituada como cidadã de direitos, com necessidades próprias e capacidades a serem desenvolvidas através da educação em todos os seus aspectos, com a ação complementar da família e da comunidade, conforme artigo 29 da LDB 9394/96:

A educação infantil, primeira etapa da educação básica, tem como finalidade o desenvolvimento integral da criança até os seis anos de idade, em seus aspectos físico, psicológico, intelectual e social, complementando a ação da família e da comunidade. (BRASIL. MINISTÉRIO DA EDUCAÇÃO E CULTURA, 1996)

Este ponto de vista sobre o atendimento até os seis anos de idade retira imediatamente da creche, ao menos na letra da Lei, seu caráter de assistencialismo para juntamente com a pré-escola, se identificar como instituição de atendimento à criança de zero a seis anos. Atualmente, a subdivisão desfaz o formato antigo, porque são consideradas como instituições de Educação Infantil a creche para as crianças entre zero e três anos e a pré-escola designada àquelas na faixa etária entre quatro e seis anos de idade; ambos os segmentos devem cuidar e educar as crianças, observando as especificidades etárias, sem descuidar da qualidade do atendimento nos sistemas municipais de ensino. Neste sentido, conforme a LDBEN/96, artigo 62 e o Parecer do CNE/CEB 04/2000, a formação de professores para atuar na Educação Infantil, poderá ser feita em curso de Licenciatura de Graduação Plena, em Universidades e Institutos Superiores de Educação, admitida como formação mínima a modalidade Normal.

O afastamento do Estado como provedor de bens e serviços e o caráter da formação de professores preconizada na LDBEN/96 figura entre os delineamentos do ponto de vista neoliberal, a exemplo da indicação da formação em nível superior, seguido do aceite do nível médio. O consentimento pela Lei da formação de professores em institutos superiores de educação desvinculados dos centros de pesquisa, segundo Cerisara (2002), tende a reduzi-los à condição de executores de técnicas, mediante uma formação deficiente, na qual não há espaço para o debate e para a reflexão, especialmente devido ao aligeiramento dos cursos e do caráter tecnicista preponderante destes. O neoliberalismo, desde sua inserção no Brasil, acarretou várias consequências 
para a educação em geral, dentre elas, desdobramentos perversos na Educação Infantil, como a formação sem a especificidade da área, cursos rápidos e a baixo custo que significam limitação de conhecimento específico e inabilidade de compreender o contexto social das crianças.

Em relação à lei 4.024, de 1961, e à lei 5.692, de 1971 (BRASIL, 1971), a atual LDBEN/96 avança ao reconhecer a Educação Infantil como a primeira etapa da educação básica, o que sugere que a educação é um processo contínuo. Outro aspecto novo é a finalidade da etapa que define o desenvolvimento integral da criança em seus aspectos físicos, psicológicos, intelectuais, sociais e culturais; além disso, apresentou diretrizes para a avaliação, sublinhando a dimensão pedagógica do atendimento; indicou a formação de seus profissionais, fundamentalmente de nível superior, e marcou prazos para que os sistemas municipais de ensino regularizem a situação de suas creches e escolas de Educação Infantil. Contudo, a nova LDBEN/96 que influenciará leis e políticas educacionais nos anos seguintes, é aprovada num momento histórico de forte ação do modelo neoliberal representado pelo BM.

Desta forma, desde 1996, a educação brasileira vem sendo regulamentada pela LDB 9394/96, de inspiração absolutamente neoliberal, privatista, quantitativa (sob a égide de ser qualitativa) e acrítica. Mesmo após dois mandatos de Luís Inácio Lula da Silva (2003/06 e 2007/10), o modelo de educação brasileira não sofreu qualquer tipo de mudança profunda e/ou significativa. Ao contrário, as instituições de ensino continuam sujeitas a índices de avaliação de desempenho, em troca de investimentos. (ALVES, 2011, p. 11)

No cenário de avanços sonhados e dos interesses internacionais, continuando deliberações educacionais a favor da infância decorrentes da nova LDBEN/96, a lei $n^{\circ}$ 9.424, de 24 de dezembro de 1996 (BRASIL. MINISTÉRIO DA EDUCAÇÃO E CULTURA1996), institui o Fundo de Manutenção e Desenvolvimento do Ensino Fundamental e de Valorização do Magistério (FUNDEF). Este Fundo passou a prever que dos $25 \%$ de recursos para educação, $15 \%$ são obrigatoriamente destinados ao Ensino Fundamental, ficando, dessa forma, apenas 10\% para atender à Educação Infantil e aos demais projetos educacionais das prefeituras, o que a deixou submetida às políticas educacionais municipais e estaduais. As políticas públicas educacionais destinadas às 
crianças de zero a seis anos permanecem influenciadas pelo ideário neoliberal, cujo principal exemplo foi o FUNDEF, ao privilegiar os recursos para o Ensino Fundamental durante uma década.

Após 10 anos, a Emenda Constitucional $n^{\circ}$ 53/2006 regulamentada pela lei $n^{\circ}$ 11.494/2007 (BRASIL, CONGRESSO NACIONAL, 2007) e pelo decreto $n^{\circ}$ 6.253/2007, substituiu O FUNDEF. A previsão de vigência do FUNDEB segue até $2020 \mathrm{com} O$ compromisso de atender, a partir do seu terceiro ano de implantação, 47 milhões de alunos da educação básica, contemplando creche, educação infantil, ensino fundamental e médio, educação especial e educação de jovens e adultos.

A aprovação do FUNDEB na versão atual se deu em meio a contendas e pressões envolvendo organizações da área de educação, especialmente da Educação Infantil. A primeira proposta de emenda constitucional acerca do FUNDEB (PEC 415/05), nitidamente arquitetada sob o ideário do BM, excluía do fundo a faixa etária de zero a três anos, o que acarretaria impactos negativos e inviabilizaria o alcance das metas propostas no PNE, naquele momento de ampliar o atendimento da Educação Infantil em 30\% em 2006 e, para 50\%, em 2011.

Em relação ao cumprimento destas metas para a Educação Infantil no atual contexto, o FUNDEB conta com modestos recursos disponíveis aos processos de intensificação da atuação na educação infantil, conforme pode ser observado no texto do atual Plano Nacional de Educação (PNE) em relação à verba necessária para alcance das propostas anunciadas.

Além disso, nesse período, a lei $\mathrm{n}^{\circ}$ 11.174, de fevereiro de 2006 (BRASIL, 2006), estabeleceu a matrícula das crianças com seis anos completos no Ensino Fundamental, passando a Educação Infantil a atender crianças até os cinco anos. Dessa forma, altera-se o dispositivo constitucional sobre o direito das crianças em instituições de Educação Infantil. A Emenda Constitucional n 53, de 19/12/2006, modifica o artigo $7^{\circ}$ da Constituição Federal, estabelecendo o direito às crianças do nascimento até cinco anos de idade, em creches e pré-escolas.

A partir de janeiro de 2009, a educação passou a assumir integralmente 0 financiamento das instituições de educação infantil, no lugar da Assistência Social. Desse 
modo, como parte da Educação Básica, a Educação Infantil deve estar sob a direção política administrativa e pedagógica das secretarias municipais de educação em todo território nacional. As creches e pré-escolas devem exercer a função de cuidar e educar de forma indissociável, superando a concepção de atendimento caritativo para os pobres (CERISARA, 2002). Ainda se encontra em construção o direito das crianças brasileiras na realidade social capitalista, visto que as crianças de zero a cinco anos não são todas atendidas. E ainda temos professores formados em nível médio, há projetos pedagógicos e formas de atendimento que ignoram a criança como cidadã (CAMPOS, 2013; CAMPOS et al., 2011).

A partir da Constituição de 1988 e da LDBEN/1996, vários documentos foram elaborados buscando-se regulamentar e criar as condições para o direito da criança à educação: Estatuto da Criança e do Adolescente (ECA), Referenciais Curriculares Nacionais para a Educação Infantil (BRASIL, 1998), Diretrizes Curriculares Nacionais para a Educação Infantil (BRASIL, 1998; 2009a), Subsídios para o Credenciamento e Funcionamento das Instituições de Educação Infantil (BRASIL, 1998),) Parâmetros Nacionais de Qualidade para a Educação Infantil (BRASIL, 2006a), Parâmetros Básicos de Infraestrutura para Instituições de Educação Infantil (BRASIL, 2006b), Política Nacional de Educação Infantil: pelo direito das crianças de zero a seis anos à Educação (BRASIL, 2006c), Indicadores da Qualidade na Educação Infantil (BRASIL, 2009b), Critérios para um atendimento em creches que respeite os direitos fundamentais das crianças (BRASIL, 2009c), e outros.

O Referencial Curricular Nacional para a Educação Infantil (RCNEI) (BRASIL, 1998) foi divulgado pelo MEC com o objetivo de oferecer uma base nacional comum para os currículos, apesar de não ser obrigatório. A integração entre educar e cuidar como função da educação infantil pôde ser considerada um avanço, bem como o conceito de educação no qual aprendizagem e desenvolvimento são processos interligados e dependentes. Até então não havia algo parecido para a Educação Infantil em âmbito federal, todavia Kuhlmann Jr. (2003, p. 52) censura as reais intenções das ações do MEC e da proposta veiculada pelo RCNEI: 
A ampla distribuição de centenas de milhares de exemplares às pessoas que trabalham com esse nível educacional mostra o poder econômico do Ministério da Educação e seus interesses políticos, muito mais voltados para futuros resultados eleitorais do que preocupados com a triste realidade das nossas crianças e instituições. Com isso, a expressão no singular - referencial - significa, de fato, a concretização de uma proposta que se torna hegemônica, como se fosse única.

Em seguida, o Conselho Nacional de Educação aprovou a Resolução CNE/CEB $n^{\circ} 1$, de 07/04/1999 (revisadas pela Resolução CNE/CBE n 5, de 17 de dezembro de 2009) que instituiu as Diretrizes Curriculares Nacionais para a Educação Infantil (DCNEI) (BRASIL, 1999) que propõe princípios, fundamentos e procedimentos para orientar as políticas públicas e a elaboração, planejamento, execução e avaliação de propostas pedagógicas e curriculares da Educação Infantil. De caráter mandatório, seriam observados compulsoriamente pelos sistemas de ensino na construção das propostas pedagógicas e no seu desenvolvimento, com abertura à sua construção com identidade local. Contudo, não obteve a mesma divulgação do RCNEI considerando se tratar de normativas para o currículo da creche e pré-escola.

O Plano Nacional de Educação (PNE 2001-2010) (BRASIL, 2001) surgiu com a proposta de a Educação Infantil ampliar sua oferta de forma a atender, em cinco anos, a $30 \%$ da população com até três anos de idade e 60\% da população de quatro a seis anos (ou quatro e cinco anos) e, até o final da década, alcançar a meta de 50\% para as crianças de zero a três anos e 80\% de quatro e cinco anos. Contudo, Conceição (2016) analisa que os resultados obtidos demonstram que na faixa de zero a três anos, a oferta cresceu em $17,1 \%$ e, a ampliação foi de $77,6 \%$ de crianças atendidas nas instituições de Educação Infantil.

Em 2006, o MEC, elaborou a Política Nacional de Educação Infantil (2006) norteado pelas diretrizes estabelecidas na Conferência Internacional de Jomtiem, ocorrida em 1990, na Tailândia, cuja primeira meta se constitui em ampliar e aprimorar o cuidado e a educação da primeira infância, de maneira integrada, notadamente para as crianças vulneráveis e desamparadas, fato, entre outros, que exemplifica a continuidade de políticas do BM no Brasil. 
O PNE (2014-2024), aprovado em 25 de junho de 2014 (BRASIL, 2014) com o compromisso de universalizar, até 2016, a educação infantil na pré-escola para as crianças de quatro a cinco anos de idade e ampliar a oferta de Educação Infantil em creches de forma a atender, no mínimo, 50\% das crianças de até três anos até o final da vigência do PNE. Segundo o Instituto Nacional de Estudos e Pesquisas Educacionais Anísio Teixeira (INEP) (BRASIL, 2016), nenhuma das metas foi realizada inteiramente, nem a que define o investimento mínimo em educação foi cumprida. O Relatório aponta que o atendimento das crianças de quatro a cinco anos passou de 72,1\%, em 2004, para 89,6\%, em 2014. No caso das crianças de até três anos, em 2014, o atendimento era de 33,3\% e, neste ano, "[...] ocorreu com uma tendência geral de ampliação das desigualdades de acesso segundo os grupos que foram comparados - fato preocupante que revela a necessidade de políticas específicas" (BRASIL. INSTITUTO NACIONAL DE ESTUDOS E PESQUISAS EDUCACIONAIS ANÍSIO TEIXEIRA, 2016, p. 46).

Esteves (2017) complementa nossa exposição afirmando um déficit de cobertura superior a 600 mil crianças de quatro e cinco anos, sendo que os mais excluídos são os sujeitos provenientes do estrato dos $25 \%$ mais pobres da população, de raça/cor preta e residentes em áreas rurais, sobretudo nas regiões Norte e Centro-Oeste. “[...] Não foi percebido maior impacto nem com a adoção de novos parâmetros para o financiamento educacional nem com a promulgação das leis que obrigam tal oferta universal, [...] como também não se percebeu relação direta entre maior cobertura e melhores indicadores de qualidade" (ESTEVES, 2017, p. 1).

Destaca-se no PNE 2014-2024 a ausência de metas sobre as condições mínimas de infraestrutura das instituições dedicadas ao ensino infantil e médio, presentes no PNE 2001-2010), e, igualmente, frustradas neste (CONCEIÇÃO, 2016).

As DCNEI (BRASIL, 1999; 2009a), assim com a Base Nacional Comum Curricular (BNCC), não são o currículo, são referência de caráter normativo do trabalho educacional com as crianças em instituições educativas porque pretendem fornecer diretrizes teóricas e práticas a serem observadas no atendimento à criança. Esse aspecto continua imperioso à Educação Infantil para que sua identidade educativa se estabeleça. 
Em 2016, a Plataforma do Letramento ${ }^{9}$ publicou entrevista com a professora Zilma de Moraes Ramos de Oliveira sobre a BNCC. Entre outras coisas, a professora afirma que a partir da concepção da criança como protagonista de suas aprendizagens, a proposta é colocar o foco do trabalho educacional na criança em sua atividade. No âmbito de experiências repletas dos objetos culturais a serem conhecidos (linguagem matemática ou a alfabética, por exemplo) e em interação com pares e adultos, a criança poderá atribuir sentido a estes objetos. Por meio da exploração, do brincar, da expressão em suas várias formas, a curiosidade seria instigada no âmbito destas experiências. Neste sentido, o arranjo curricular definido na BNCC para a Educação Infantil está fundamentado em experiências organizadas a partir de cinco campos de experiências (o eu, o outro e o nós; corpo, gestos e movimentos; escuta, fala, pensamento e imaginação; traços, sons, cores e imagens; espaços, tempos, quantidades, relações e transformações). Cada um dos campos de experiências conta com objetivos de aprendizagem próprios que não têm relação com as disciplinas escolares. As experiências seriam preparadas e realizadas com as crianças, de forma a garantir seu direito de aprender, conforme suas especificidades e modos de compreender.

Algumas das iniciativas mencionadas e políticas públicas confirmam que as legislações e documentos oficiais do MEC que consideram a proteção da infância evoluíram de forma expressiva nas últimas décadas. Contudo, ainda revelam-se insuficientes para suplantar o histórico de descaso e abandono que estabeleceram o cenário atual de disparidades de condições das crianças. Essa realidade social evidencia que o fato de a criança ter direitos proclamados em legislações não é garantia de efetivação dos direitos assegurados, como assinalam os estudos de Campos (2013); Campos et al. (2011) e Campos, Füllgraf e Wiggers . (2006). Não obstante, conforme Rocha (1999), o trabalho em creches, dentre outras questões, ainda revela a presença de políticas públicas focalizadas, seletivas e compensatórias, expressas pelo número insuficiente de creches mantidas pelo poder público, pela predominância de critérios socioeconômicos e pelo trabalho extradomiciliar materno como indicador de acesso às vagas, pela carência de profissionais com formação específica para o trabalho, pela

\footnotetext{
${ }_{9}$ Disponível em: <http://www.plataformadoletramento.org.br/em-revista-entrevista-detalhe/1049/zilma-demoraes-ramos-de-oliveira-educacao-infantil-na-base-nacional-comum-curricular.html>.
} 
expressiva quantidade de crianças nas filas por vagas nas instituições, pela imprecisão e/ou dificuldades orçamentárias vigentes nas instituições, e pelos contrastes entre os objetivos pedagógicos propostos e as legítimas condições de trabalho. A legitimidade dessas instituições, hoje, segue em busca da ampliação e do oferecimento de atendimento de qualidade às famílias e às crianças.

Observamos o campo da Educação Infantil desde a década de 1990 do século XX, defendendo progressivamente os direitos da criança, a função educativa da creche e préescola e, de outro lado, a recorrência dos interesses do Banco Mundial em financiar a educação da primeira infância com base no seu sistema de idéias e medidas, ciente que este é um investimento social e econômico no futuro.

A análise do panorama do atendimento à infância no Brasil demonstra, sobretudo, a história da Educação Infantil associada à história da assistência e à tutela da criança pobre pelo Estado nos diferentes períodos históricos. O conceito de infância na contemporaneidade não pode ser desvinculado da história, das distintas concepções em torno da criança que engendraram sua condição atual, pois segundo Oliveira (2002, p. 79) “[...] o exame da história da educação infantil tem evidenciado que a ideia de infância é uma construção histórica e social, coexistindo em um mesmo momento múltiplas idéias de criança e de desenvolvimento infantil”. Sarmento (2007, p. 29) completa: “[...] no interior do mesmo espaço cultural, a variação das concepções da infância é fundada em variáveis como a classe social, o grupo de pertença étnica ou nacional, a religião predominante, o nível de instrução da população [...]." A ideia de infância vem se construindo de acordo com a história e reproduz os valores e interesses presentes na sociedade em diferentes épocas. Assim, reconstituir a trajetória da Educação Infantil nos remete a avanços e retrocessos. A contradição é um aspecto persistente mostrado pela dissociação entre legislação e realidade e a discrepância de concepções no que se refere às funções exercidas. Em âmbito geral, as políticas públicas para esta etapa ainda se encontram muito aquém do que poderíamos nomear de avanços significativos. 


\section{Considerações}

No Brasil e no mundo, vimos acontecer ao longo da história o atendimento institucional à criança pequena a partir de concepção bem divergente sobre sua finalidade social. Muitas dessas instituições surgiram com o objetivo de receber somente crianças de baixa renda. Em vários momentos do percurso histórico de atendimento à infância, creches e programas de pré-escolas foram propostos como estratégia para combater a pobreza e resolver os problemas sociais ligados à sobrevivência das crianças; justificativa usada para implantação de atendimento de baixo custo nos moldes da ideologia do Banco Mundial e de outros organismos internacionais no campo da política neoliberal, com aplicações orçamentárias insuficientes, escassez de recursos materiais, instalações físicas impróprias, formações aligeiradas de profissionais e elevadas proporções de crianças por adultos.

No Brasil, creche e pré-escola se constituíram historicamente em dois campos diferentes de atuação, sendo que seu surgimento e transformações estão envolvidos num conjunto de fatores sociais, culturais, econômicos e políticos que resultaram das rupturas e continuidades de cada período histórico.

O movimento da pré-escola, desde a sua origem, ratifica um caráter educativo, nomeadamente de preparação para a escola regular com respaldo na teoria da privação cultural e programas compensatórios. A creche, por sua vez, transcorre a sua história com a marca do assistencialismo como particularidade do seu atendimento à criança. Evoluiu absolutamente relacionada às alterações do papel feminino na sociedade e suas repercussões na estrutura familiar, em especial na educação dos filhos pequenos. Na sua raiz, a creche foi uma instituição para asilar e salvar crianças pobres e desamparadas; o seu funcionamento tinha por base atividades de higiene, consideradas arriscada entre as camadas populares, e a preocupação com a saúde, tendo em vista o elevado coeficiente de mortalidade infantil durante décadas no país. Nos tempos atuais, a legislação sinaliza na direção de um atendimento que observe o direito constitucional da criança integrando cuidados e educação para todo segmento que compreende as crianças menores de seis anos de idade. Hoje, não atende aos direitos infantis apenas abrigar, é preciso cuidar e educar sem retroceder à antiga dicotomia. 
A educação da infância, atualmente Educação Infantil, quase nunca foi prioridade do Estado, pois a análise do seu percurso demonstra a recorrência de políticas de baixo custo, mesmo quando a política decorreu dos órgãos educacionais oficiais, tendência intensificada a contar da década de 1990 do século XX pelas intervenções dos organismos internacionais, conforme comentado antes.

Nesta perspectiva, para o século XXI temos, dentre tantos, o desafio de ampliar o acesso e aperfeiçoar a qualidade do atendimento com políticas e propostas pensadas para as peculiaridades da faixa etária; propor projetos de formação dos profissionais articulados ao conhecimento já adquirido sobre as necessidades e características infantis, tendo em vista, sobretudo, a garantia do direito à educação das crianças brasileiras com distintivas emancipatórias.

\section{Referências}

ALVES, Ronaldo Sávio Paes. Neoliberalismo e educação: uma década de intervenções do Banco Mundial nas Políticas Públicas do Brasil (2000 - 2010). In: SIMPÓSIO NACIONAL DE HISTÓRIA - ANPUH, São Paulo, XXVI, julho 2011. Anais... 2011. p. 1-16. Disponível em: <http://www.snh2011.anpuh.org/resources/anais/14/1300894657_ARQUIVO_artigoNEOLIB ERALISMOEEDUCACAO.pdf.>. Acesso em: 4 de jan. 2017.

ALVIM, Maria Rosilene Barbosa; VALLADARES, Lícia do Prado. Infância e sociedade no Brasil: uma análise da literatura. BIB - Boletim Informativo e Bibliográfico de Ciências Sociais. Rio de Janeiro: ANPOCS, n. 26, p. 3-37, $2^{\circ}$ semestre, 1988.

ARIÈS, Philippe. História social da criança e da família. 2. ed. Rio de Janeiro: LCT, 1981.

AMOROSO, Marta. A longa era da catequese indígena. In: FARIA FILHO, Luciano Mendes de; ARAÚJO, Vania Carvalho de. (Orgs.) História da educação e da assistência à infância no Brasil. Vitória: EDUFES, 2011, p. 207-244. 
BRASIL. Congresso Nacional. Lei n. 11.494, de 20 de junho de 2007: Regulamenta o Fundo de Manutenção e Desenvolvimento da Educação Básica e de Valorização dos Profissionais da Educação - FUNDEB -, de que trata o art. 60 do Ato das Disposições Constitucionais Transitórias; altera a Lei no. 10.195, de 14 de fevereiro de 2001; revoga dispositivos das Leis nos. 9.424, de 24 de dezembro de 1996, 10.880, de 9 de junho de 2004, e 10.845, de 5 de março de 2004; e dá outras providências. Brasília, DF, 2007.

BRASIL. Constituição da República Federativa do Brasil: promulgada em 5 de outubro de 1988. Brasília: Centro Gráfico do Senado Federal, 1988.

BRASIL. Decreto n. 2.745, de 13 de fevereiro de 1861. Cria o Instituto dos Menores Artesãos da Casa de Correção da Corte e dá-lhe Regulamento. In: COLEÇÃo das leis do Império do Brasil, Rio de Janeiro, v. 1, parte 2, p. 117-120, 1861.

BRASIL. Instituto Nacional de Estudos e Pesquisas Educacionais Anísio Teixeira. Relatório do $1^{\circ}$ ciclo de monitoramento das metas do PNE: biênio 2014- 2016. Brasília, DF: Inep, 2016. Disponível em:

<http://download.inep.gov.br/outras_acoes/estudos_pne/2016/relatorio_pne_2014_a_201 6.pdf>. Acesso em: 30 set. 2017

BRASIL. Lei n. 8.069 de 13 julho de 1990. Estatuto da Criança e do Adolescente. Diário Oficial da União, Brasília, 16 jul., 1990.

BRASIL. Lei n ${ }^{\circ}$ 13.005, de 25 de junho de 2014. Aprova o Plano Nacional de Educação - PNE e dá outras providências. Diário Oficial da União, Brasília, DF, 26 jun., 2014. Seção 1, p. 1. Disponível em: http://www.planalto.gov.br/ccivil_03/_ato2011-014/2014/lei/l13005.htm. Acesso em: 5 fev. 2017.

BRASIL. Ministério da Educação. Critérios para um atendimento em creches que respeite os direitos fundamentais das crianças. Brasília: SEF/ COEDI: 2009.

BRASIL. MINISTÉRIO DE EDUCAÇÃO. CONSELHO NACIONAL DE EDUCAÇÃO. Câmara de Educação Básica. Resolução CNE/MEC, № 1, de abril de 1999. Diretriz Curricular Nacional de Educação Infantil. Brasília: D.O.U. de 13 de abril de 1999. Seção 1, p.18. Disponível em: <http://portal.mec.gov.br/cne/arquivos/pdf/CEB0199.pdf>. Acesso em 30 set. 2017.

BRASIL. MINISTÉRIO DE EDUCAÇÃO. CONSELHO NACIONAL DE EDUCAÇÃO. Câmara de Educação Básica. Resolução CNE/MEC, N 5 , de 17 de dezembro 2009. Diretriz Curricular Nacional de Educação Infantil. Brasília: D.O.U. de 18 de dezembro de 2009. Disponível em: <http://portal.mec.gov.br/conaes-comissao-nacional-de-avaliacao-da-educacao-superior/323secretarias-112877938/orgaos-vinculados-82187207/13684-resolucoes-ceb-2009>. Acesso em: 30 set. 2017.

BRASIL. Ministério da Educação e Cultura. Lei n. 9.394: Lei de Diretrizes e Bases da Educação Nacional. Brasília, DF: MEC, 1996.

BRASIL. Ministério da Educação. Conselho Nacional de Educação. Parâmetros Básicos de Infraestrutura para Instituições de Educação Infantil. Brasília: MEC/SEB, 2006. 
BRASIL. Ministério da Educação. Conselho Nacional de Educação. Resolução CEB n.05, 17 dez. 2009: Institui as diretrizes curriculares nacionais para a educação infantil. Diário Oficial República Federativa do Brasil, Brasília, DF, 18 dez. 2009. Seção 1, p. 18.

BRASIL. Ministério da Educação. Secretaria de Educação Fundamental. LEI No 11.274, de 6 de fevereiro de 2006. Ensino fundamental de nove anos: orientações para a inclusão da criança de 6 anos de idade. Brasília, DF, 2006. Disponível em:

<http://portal.mec.gov.br/seb/arquivos/pdf/Ensfund/ensifundganobasefinal.pdf>. Acesso em: 30 set. 2017.

BRASIL. Ministério da Educação. Secretaria de Educação Básica. Política Nacional de Educação Infantil: pelo direito das crianças de zero a seis anos à educação. Brasília: MEC/ SEB, 2006a.

BRASIL. Ministério da Educação. Secretaria de Educação Básica. Indicadores da qualidade na Educação Infantil. Brasília: MEC/SEB, 2009.

BRASIL. Ministério da Educação. Secretaria de Educação Básica. Parâmetros nacionais de qualidade para a educação infantil. Brasília: MEC/SEB, 2006b.

BRASIL. Ministério da Educação e Cultura. Secretaria Geral. Comissão de Coordenação Geral. Programa Nacional de Educação Pré-Escolar. Brasília/DF, 1981. Disponível em: <http://www.dominiopublico.gov.br/pesquisa/DetalheObraForm.do?select_action=\&co_o bra $=25150>$. Acesso em: 16 jan. 2017

BRASIL. Secretaria de Educação Fundamental. Coordenação Geral de Educação Infantil. Referencial Curricular Nacional para a Educação Infantil. Brasília, DF: MEC/SEF/COEDI, 1998.

BRASIL. Secretaria de Educação Fundamental. Departamento de Políticas Educacionais. Coordenação Geral de Educação Infantil. Política Nacional de Educação Infantil. Brasília, DF: MEC/SEF/DPE/COEDI, 1994.

BRASIL. Lei $n^{\circ}$ 5.692/71 de 11 de agosto de 1971. Fixa Diretrizes e Bases para o ensino de $1^{\circ}$ e $2^{\circ}$ graus, e dá outras providências. Disponível

em: <http://www2.camara.gov.br/legislacao/publicacoes/republica>. Acesso: 30set, 2017.

BUJES, Maria Isabel Edelweiss. Escola Infantil: pra que te quero? In: CRAIDY, Carmen Maria; Gládis Elise Kaercher (Orgs.). Educação infantil: pra que te quero? Porto Alegre: Artmed, 2001, p. 13-22.

CAMPOS, Maria Malta. Entre as políticas de qualidade e a qualidade das práticas.

Cadernos de Pesquisa, São Paulo, v. 43, n. 148, p. 22-43, jan./abr., 2013.

CAMPOS, Maria Malta et al. A qualidade da educação infantil: um estudo em seis capitais brasileiras. Cadernos de Pesquisa, São Paulo, v. 41, n. 142, p. 20-54, jan./abr., 2011. 
CAMPOS, Maria Malta; FÜLLGRAF, Jodete; WIGGERS, Verena. A qualidade da educação infantil brasileira: alguns resultados de pesquisa. Cadernos de Pesquisa, São Paulo, v. 36, n. 127, p. 87-128, jan./abr., 2006.

CONCEIÇÃO, Sergio Henrique da. Perspectivas e desafios do Plano Nacional de Educação (PNE) (2014-2024) no contexto do financiamento da educação básica. Educação em Revista, Marília, v. 17, n. 1, p. 35-54, Jan./Jun., 2016.

CERISARA, Ana Beatriz. O referencial curricular nacional para a educação infantil no contexto das reformas. Educação e Sociedade, Campinas, v. 23, n. 80, p. 326-34, set., 2002.

CIVILETTI, Maria Vitória Pardal. O cuidado às crianças pequenas no Brasil escravista. Cadernos de Pesquisa, São Paulo, n. 76, p. 31-40, fev., 1991.

DEL PRIORE. Mary. História das crianças no Brasil. São Paulo: Contexto, 2004.

DIDONET, Vital. Creche: a que veio... para onde vai...Em Aberto, Brasília, v.1, n.73, p.1-161, jul., 2001.

ESTEVES, Luiz Carlos Gil. A pré-escola e o direito à educação: aportes para um debate. Est. Aval. Educ., São Paulo, v. 28, n. 67, p. 102-131, jan./abr. 2017. Disponível em;:<http://publicacoes.fcc.org.br/ojs/index.php/eae/article/view/4082>. Acesso em: 26 jan. 2017.

FARIA, Ana Lúcia Goulart. As origens da rede pública municipal de educação infantil na cidade de São Paulo. Proposições, v.6, n. 2 (17), 1995, p. 34-45.

FARIAS, Mabel. Infância e educação no Brasil nascente. In: VASCONCELOS, Vera Maria Ramos (Org.). Educação da infância: história e política. Rio de Janeiro: DP\&A, 2005. p. 3349.

FILHO, Moncorvo. Histórico da proteção à infância no Brasil, 1500-1922. Rio de Janeiro, Emp. Graphica Ed., 1926.

GÓIS JUNIOR, Edivaldo. Movimento higienista na história da vida privada no Brasil: do homogêneo ao heterogêneo. ConScientiae Saúde ConScientiae Saúde, São Paulo: Universidade Nove de Julho. n 1, p. 47-52, 2002. ISSN 1677-102816. Disponível em: <http://www.redalyc.org/articulo.oa?id=92900109>. Acesso em 16 de maio de 2017.

GUIMARÃES, Célia Maria. Leitura e escrita na pré-escola - o processo de ensino da leitura e escrita: idéias, concepções e influencias na prática educacional dos professores da préescola municipal de Presidente Prudente, SP. 1995 (Mestrado em Educação) - Programa de Pós-Graduação em Educação, Faculdade de Filosofia e Ciências - Universidade Estadual Paulista - Presidente Prudente. 
KRAMER, Sônia. A infância e sua singularidade. In: BRASIL, Ministério da educação.

Ensino Fundamental de nove anos: orientações para a inclusão da criança de seis anos. Brasília: FNDE, Estação Gráfica, 2006, p. 15-25.

KRAMER, Sônia. A política do pré-escolar no Brasil: a arte do disfarce. 7. ed. São Paulo: Cortez, 2003.

KRAMER, Sonia (Org.). Com a pré-escola nas mãos: uma alternativa curricular para a Educação Infantil. São Paulo: Editora Ática, 1991.

KRAMER, Sonia (Org.). A política do pré-escolar no Brasil: a arte do disfarce. 5. ed. São Paulo: Cortez, 1995.

KISHIMOTO, Tizuko Morchida. A pré-escola em São Paulo (1877 a 1940). São Paulo: Loyola, 1988.

KUHLMANN JR., Moysés. Infância e Educação Infantil: uma abordagem histórica. 3 ed. Porto Alegre: Mediação, 2004

KUHLMANN JUNIOR, Moysés. A circulação das ideias sobre a educação das crianças: Brasil, início do século XX. In: FREITAS, Marcos Cezar de; KUHLMANN JUNIOR, Moysés. (Orgs.). Os intelectuais na história da infância. São Paulo: Cortez, 2002. p. 459-501.

KUHLMANN JUNIOR, Moysés. O jardim de infância e a educação das crianças pobres: final do século XIX, início do século XX. In: MONARCHA, Carlos (Org.). Educação da infância brasileira: 1875-1983. Campinas, SP: Autores Associados, 2001. p. 3-30. (Coleção educação contemporânea).

KUHLMANN JUNIOR, Moysés. Histórias da educação infantil brasileira. Revista Brasileira de Educação, n. 14, p. 5-18, maio-ago., 2000.

KUHLMANN JUNIOR, Moysés. Educação infantil e currículo. In: FARIA, Ana Lúcia Goulart de; PALHARES, Marina Silveira. Educação infantil pós LDB: rumos e desafios. São Paulo: Autores Associados, 1999.

KUHLMANN JUNIOR, Moysés. Infância e educação infantil: uma abordagem histórica. Porto Alegre: Mediação, 1998.

KUHLMANN JUNIOR, Moysés. As exposições internacionais e a difusão das creches e jardins de infância (1867-1922). Pro-posições, v. 7, n. 3, p. 24-35, 1996.

KUHLMANN JUNIOR, Moysés. Instituições pré-escolares assistencialistas no Brasil (18991922). Cadernos de Pesquisa, São Paulo, n. 78, p. 17-26, ago., 1991.

MARCILIO, Maria Luiza. A roda dos expostos e a criança abandonada na História do Brasil. 1726-1950. In: FREITAS, Marcos Cezar de (Org.). História social da infância no Brasil. 2. Ed. São Paulo: Cortez, 1999. 
MONTENEGRO, Maria Thereza Tavares. A educação moral como parte da formação para o cuidado na educação infantil. 1999, 177 f. Tese (Doutorado em Psicologia Social) Pontifícia Universidade Católica de São Paulo, São Paulo, 1999.

OLIVEIRA, Zilma de Moraes Ramos. Educação Infantil: fundamentos e métodos. 7 ed. São Paulo: Cortez, 2011.

OLIVEIRA, Zilma Ramos de. Educação infantil: fundamentos e métodos. São Paulo: Cortez, 2005.

OLIVEIRA, Stela Maris Lagos. A legislação e as políticas nacionais para a educação infantil: avanços, vazios e desvios. In: MACHADO, Maria Lúcia (Org.) Encontros e desencontros em educação infantil. São Paulo: Cortez, 2002.

OLIVEIRA, Stela Maris Lagos. Contribuições para o esboço de uma proposta curricular para a formação de educadores de creche em nível de $2^{\text {a }}$ Grau. In: ROSEMBERG, Fulvia. CAMPOS, Maria Malta. M, VIANA, C.P. A formação do educador de creche: sugestões e propostas curriculares. São Paulo: FCC/DPE, 1992.

REDIN, Euclides. Atendimento à criança pequena no Brasil. São Paulo: FDE, 1988. (Série Ideias, 20).

RIZZINI, Irene; RIZZINI, Irma. A institucionalização de crianças no Brasil. Editora PUCRio, São Paulo: Loyola, 2004.

RIZZINI, Irene. 0 século perdido: raízes históricas das políticas públicas para a infância no Brasil. Rio de Janeiro: Petrobrás-BR: Ministério da Cultura: USU Ed. Universitária: Amais, 1997.

RIZZINI, Irma. Assistência à infância no Brasil: uma análise de sua construção. Rio de Janeiro: Ed. Universitária Santa Úrsula, 1993.

ROCHA, Eloisa Acires Candal. A pesquisa em educação infantil no Brasil: trajetória recente e perspectivas de consolidação de uma pedagogia. Florianópolis: UFSC, 1999.

ROSEMBERG, Fúlvia. Panorama da educação infantil brasileira contemporânea. In: SIMPÓSIO EDUCAÇÃO INFANTIL: CONSTRUINDO O PRESENTE, Brasília, 2003. Anais... Brasília: UNESCO, 2003. p. 33-81.

ROSEMBERG, Fúlvia. Sísifo e a educação infantil brasileira. Revista Pró-Posições, v. 14, n. 1 (40), Jan./abr., 2003.

ROSEMBERG, Fúlvia. Organizações multilaterais, estado e políticas de educação infantil. Cadernos de Pesquisa, São Paulo, n. 115, mar., 2002.

ROSEMBERG, Fúlvia. Do embate para o debate: educação e assistência no campo da educação infantil. In: MACHADO, Maria Lúcia. (Org.) Encontros e desencontros em educação infantil. São Paulo: Cortez, 2002a. p. 63-78. 
ROSEMBERG, Fúlvia. Avaliação de programas, indicadores e projetos em educação infantil. Revista Brasileira de Educação, n. 16, jan./abr. 2001, p. 19-26.

ROSSETTI-FERREIRA, Maria Clotilde; RAMON, Fabiola; SILVA, Ana Paula Soares. As políticas de atendimento à criança pequena nos países em desenvolvimento. Cadernos de Pesquisa. São Paulo, n. p. 115, p. 65-101, mar., 2002.

SARMENTO, Manuel Jacinto. VASCONCELLOS, Vera Maria Ramos. (Orgs.) Infância (in)visível. Araraquara: Junqueira\&Marin, 2007. 